Revista Eletrônica de Direito Processual - REDP.

Rio de Janeiro. Ano 13. Volume 20. Número 1. Janeiro a Abril de 2019

Periódico Quadrimestral da Pós-Graduação Stricto Sensu em Direito Processual da UERJ

Patrono: José Carlos Barbosa Moreira (in mem.). ISSN 1982-7636. pp. 182-215

www.redp.uerj.br

\title{
BREVE ANÁLISE EMPÍRICA DA TUTELA DE EVIDÊNCIA (ART. 311 DO CÓDIGO DE PROCESSO CIVIL) NO ÂMBITO DO TJSP ${ }^{1}{ }^{2}$
}

\section{THE PROVISIONAL INJUCTION OF EVIDENCE (ART. 311 OF BRAZILIAN CIVIL PROCEDURE CODE) IN THE JUSTICE COURT OF SÃO PAULO}

Fernando da Fonseca Gajardoni Doutor e Mestre em Direito Processual Civil pela Faculdade de Direito da USP (FD-USP). Professor Doutor de Direito Processual da Faculdade de Direito de Ribeirão Preto da USP (FDRP-USP). Juiz de Direito no Estado de São Paulo. Ribeirão Preto/SP. E-mail: fernando.gajardoni@usp.br

Sara Ribas Ortigosa Leite Bacharel em Direito pela Faculdade de Direito de Ribeirão Preto da USP (FDRP-USP). Advogada. Ribeirão Preto/SP.

RESUMO: Apesar da inegável inovação científica e teórica da reforma processual, o intuito deste trabalho foi identificar o impacto da introdução das novas hipóteses do art. 311, verificando se a tutela de evidência cumpre os objetivos comunicados no Anteprojeto da reforma, bem como se as novas situações incluídas pelo Código conseguem contemplar uma quantidade significativa de processos e se, efetivamente, atingem as reais causas dos problemas que obstruem o Judiciário. Para isso, foram consultados processos do Tribunal de Justiça do Estado de São Paulo, através do Portal de Serviços $e$-saj.

PALAVRAS CHAVE. Tutelas provisórias. Tutela de evidência. Pesquisa empírica.

ABSTRACT: Despite the undeniable scientific and theoretical innovation of procedural reform, the purpose of this paper was to identify the impact of the introduction of the new

\footnotetext{
${ }^{1}$ Artigo recebido em 20/02/2019 e aprovado em 30/03/2019.

${ }^{2}$ Texto originado do trabalho de conclusão de curso de graduação, apresentado pela $2^{\text {a }}$ autora com orientação do $1^{\circ}$ autor, para obtenção do título de bacharel em Direito na Faculdade de Direito de Ribeirão Preto da USP (FDRP-USP).
} 
Revista Eletrônica de Direito Processual - REDP.

Rio de Janeiro. Ano 13. Volume 20. Número 1. Janeiro a Abril de 2019

Periódico Quadrimestral da Pós-Graduação Stricto Sensu em Direito Processual da UERJ

Patrono: José Carlos Barbosa Moreira (in mem.). ISSN 1982-7636. pp. 182-215

www.redp.uerj.br

hypotheses of article 311 , verifying whether the provisional injunction of evidence fulfills the objectives communicated in the Draft Bill of the reform, as well as whether the new situations included in the Code can contemplate a significant number of cases and if they actually reach the real causes of the problems that obstruct the Judiciary. For this purpose, the Justice Court of São Paulo State was consulted through the $e$-saj Services Portal.

KEYWORDS. Provisional injunctions. Provisional injunctions of evidence. Empirical research.

SUMÁRIO: 1. Introdução. 2. Tutela de evidência sancionatória (inciso I). 3. Tutela de evidência fundada em precedente vinculante (inciso II). 4. Tutela de evidência baseada no direito do depositante (inciso III). 5. Tutela de evidência fundada em prova documental (Inciso IV). 6. Conclusão. 7. Referências bibliográficas.

\section{INTRODUÇÃO}

O Código de Processo Civil de 2015 introduziu de forma expressa a tutela de evidência como espécie de tutela provisória, consolidando um instrumento apto a inverter o ônus do tempo do processo e contornar o conhecido problema do tempo inimigo, tradicionalmente causador do dano marginal ao processo. Para isso, a lei autoriza o deferimento de uma tutela em cognição sumária independentemente do periculum in mora exigido nas tutelas de urgência (art. 300 CPC).

A tutela de evidência não é inédita no Direito Processual Brasileiro, de maneira que já encontrava guarida em procedimentos especiais previstos de forma esparsa no antigo Código (como na ação monitória), e em legislação extravagante (como nos casos de alienação fiduciária disciplinados pelo Decreto-Lei 911/69), bem como no revogado art. 273, I do CPC/73. No entanto, a nova legislação tem o mérito de sistematizar o assunto e declinar em lei a expressão que já era atribuída pela doutrina e pela jurisprudência, mas que não constava da antiga sistemática.

Nessa nova estruturação do diploma, foi mantida a hipótese antes contemplada no revogado art. 273, I do CPC/73, agora insculpida no inciso I do art. 311, e foram incluídas mais três situações que admitem o deferimento do bem da vida à parte que tem o direito 
Revista Eletrônica de Direito Processual - REDP.

Rio de Janeiro. Ano 13. Volume 20. Número 1. Janeiro a Abril de 2019

Periódico Quadrimestral da Pós-Graduação Stricto Sensu em Direito Processual da UERJ

Patrono: José Carlos Barbosa Moreira (in mem.). ISSN 1982-7636. pp. 182-215

www.redp.uerj.br

evidente em seu favor, independentemente do trânsito em julgado da decisão, viabilizando o cumprimento provisório da sentença desde logo.

\section{TUTELA DE EVIDÊNCIA SANCIONATÓRIA (INCISO I)}

Conforme adiantado, o inciso I reproduziu integralmente o teor já contemplado pelo revogado art. 273, I, do CPC/73, sendo, portanto, a situação de menor relevância nesse estudo. Por isso, basta comentar que a pesquisa jurisprudencial levantada comprova exatamente o que pesquisas teóricas já indicavam a respeito do tema, isto é, que esta hipótese não tem ampla aplicabilidade.

Isso se dá porque o magistrado conta com outros instrumentos processuais aptos a coibir ou sancionar a conduta protelatória da parte (como o indeferimento de atos protelatórios, multas e responsabilidade por perdas e danos) e tem, ainda, a possibilidade de se aplicar o julgamento antecipado de mérito nessa circunstância ${ }^{3}$.

De fato, em busca das decisões de $1^{\circ}$ grau no banco de dados do Tribunal de Justiça de São Paulo, inserindo como termo de busca, no campo "Pesquisa Livre", a expressão "art. 311, I", a pesquisa retornou entre os anos de 2016, quando o Código atual entrou em vigor, e 2017, apenas 27 processos.

Em 2016, dos 12 processos consultados, 10 efetivamente deferiram a tutela de evidência com fundamento neste inciso. Um dos processos indeferiu a tutela de evidência requerida e o outro versava sobre tema estranho ao pesquisado.

Em 2017, dos 15 processos identificados, 12 deferiram a tutela de evidência. Um processo foi julgado extinto sem resolução de mérito por falta de interesse processual. Em um dos processos a tutela de evidência não foi deferida e o artigo apenas foi suscitado para fortalecer sua argumentação. Um não versou expressamente sobre tutela de evidência.

Isso significa que, em primeiro grau, apenas em 22 processos foi concedida a tutela de evidência no lapso de tempo pesquisado, o que comprovou a baixa representatividade do inciso I do art. 311 nas decisões.

\footnotetext{
${ }^{3}$ DIDIER JUNIOR, Fredie; BRAGA, Paula Sarno; OLIVEIRA, Rafael Alexandria de. Curso de Direito Processual Civil: teoria da prova, direito probatório, ações probatórias, decisão, precedente, coisa julgada e antecipação dos efeitos da tutela. 10. ed. v. 2. Salvador: JusPodivm, 2015. p. 622-624.
} 
Revista Eletrônica de Direito Processual - REDP.

Rio de Janeiro. Ano 13. Volume 20. Número 1. Janeiro a Abril de 2019

Periódico Quadrimestral da Pós-Graduação Stricto Sensu em Direito Processual da UERJ

Patrono: José Carlos Barbosa Moreira (in mem.). ISSN 1982-7636. pp. 182-215

www.redp.uerj.br

\section{TUTELA DE EVIDÊNCIA FUNDADA EM PRECEDENTE VINCULANTE (INCISO II)}

Antes da edição do CPC/2015, quando os fundamentos da defesa do demandado fossem contrários a súmula ou jurisprudência pacífica dos tribunais superiores, já existia entendimento no sentido de ser possível a concessão da tutela de evidência, com fundamento em abuso do direito de defesa ${ }^{4}$. Logo, a situação hoje descrita no inciso II do art. 311, com um pouco de boa vontade interpretativa, já podia ser objeto de tutela da evidência.

De todo modo digna de encômios a alteração legislativa, pois que além da melhor sistematização do instituto, agora o CPC autoriza a tutela da evidência na situação inversa: quando a pretensão autoral for comprovada documentalmente e houver tese firmada em julgamento de casos repetitivos (art. 928 do CPC) em abono à tese do postulante. Sem contar a expressa previsão da possibilidade de concessão da tutela provisória liminarmente (art. 311, parágrafo único, CPC).

No entanto, pela análise da jurisprudência consultada, também verifica-se, nos anos de 2016 e de 2017, um número muito pequeno de processos nos quais foi deferida a tutela de evidência com fundamento no inciso II do art. 311, do CPC.

Na pesquisa realizada no Portal $e$-saj do Tribunal de Justiça de São Paulo (conforme parâmetros indicados adiante) foram detectados apenas 15 processos que deferiram a tutela de evidência em $1^{\circ}$ grau.

Além disso, cabe a observação de que, quanto a esse inciso, é possível que acabe ocorrendo a mesma situação constatada, de forma ainda mais nítida, no inciso IV, no sentido de existir uma sobreposição das hipóteses que autorizam a incidência da tutela de evidência e do julgamento antecipado de mérito.

Isso ocorre porque a situação descrita no inciso II do art. 311 poderia ser resolvida também pelo julgamento conforme o estado do processo, já que, se a pretensão da parte se fundar em precedente vinculante e suas alegações puderem ser comprovadas exclusivamente por meio dos documentos trazidos aos autos, estará preenchida tanto a hipótese da tutela de evidência quanto a do julgamento do mérito previsto no art. 355, I, tornando desnecessária a instrução probatória 5 .

\footnotetext{
${ }^{4}$ LOPES, Bruno Vasconcelos Carrilho. Tutela Antecipada Sancionatória: art. 273, inc. II, do Código de Processo Civil. São Paulo: Malheiros, 2006. p. 118-119.

${ }^{5}$ RODRIGUES, Marco Antonio; RANGEL, Rafael Calmon. A tutela de evidência como técnica de atuação judicial, Revista de Processo, São Paulo, v. 271, ano 42, p.266, set. 2017.
} 
Revista Eletrônica de Direito Processual - REDP.

Rio de Janeiro. Ano 13. Volume 20. Número 1. Janeiro a Abril de 2019

Periódico Quadrimestral da Pós-Graduação Stricto Sensu em Direito Processual da UERJ

Patrono: José Carlos Barbosa Moreira (in mem.). ISSN 1982-7636. pp. 182-215

www.redp.uerj.br

Apesar de o julgamento antecipado de mérito também abreviar o iter

procedimental, é cediço que esses institutos não se confundem. O julgamento antecipado tem cabimento quando o réu é revel e o direito do autor é plausível, quando a questão controvertida for matéria de direito ou se os fatos forem incontroversos, tornando desnecessária a fase instrutória ${ }^{6}$.

Ademais, o julgamento antecipado do mérito consiste em verdadeira decisão final, irrevogável pelo juiz, havendo tão somente uma antecipação temporal do momento de proferimento da sentença. Existe, portanto, cognição exauriente da matéria ${ }^{7}$.

Por isso, o julgamento antecipado do mérito desafia apelação e, em regra, forma coisa julgada material, como é próprio das sentenças definitivas que decorrem da cognição judicial exauriente; enquanto as decisões a respeito da tutela de evidência são impugnáveis por agravo de instrumento e não se sujeitam à coisa julgada material, como é próprio das decisões resultantes da cognição sumária do juiz ${ }^{8}$.

Na teoria, a ideia é que a tutela de evidência teria um grau de comprovação do direito maior que o exigido quando há urgência, mas ainda inferior ao que existe nas decisões com cognição judicial exauriente ${ }^{9}$. No entanto, apesar de essa distinção ser muito bem delimitada na doutrina, não é tão clara na prática forense, de forma que, na grande maioria dos casos contemplados pelo inciso II do art. 311 do CPC, as hipóteses de aplicação da tutela de evidência e de julgamento antecipado do mérito acabam coincidindo e são utilizados concomitantemente como forma de otimizar o tempo do processo ao se proferir uma decisão definitiva.

Com o intuito de verificar essa hipótese, foi realizada nova consulta dos julgados de $1^{\circ}$ grau no banco de dados do Tribunal de Justiça do Estado de São Paulo, por meio do Portal de Serviços $e$-saj.

Na pesquisa, foi incluído, no campo "Pesquisa Livre", sem qualquer outro filtro de classe ou assunto, o termo "art. 311, II", retornando, no ano de 2016, 9 processos, e, no ano de 2017,14 processos.

\footnotetext{
${ }^{6}$ CASTRO, Daniel Penteado de. Antecipação de tutela sem o requisito da urgência: panorama geral e perspectivas no novo Código de Processo Civil. Salvador: JusPodivm, 2017. p.53-54.

${ }^{7}$ ALVIM, Arruda. Manual de Direito Processual Civil. 14. ed. São Paulo: Revista dos Tribunais, 2011. p.876.

${ }^{8}$ SCHEIDT, Emiliane. A tutela de evidência no Novo Código de Processo Civil, Revista da Escola Superior de Magistratura do Estado de Santa Catarina, Santa Catarina, v. 23, n. 29, p.195, 2016.

9 PEREIRA, Alexandre Ferrer Silva. A efetividade da Tutela Antecipada de Evidência no Estado Democrático de Direito. Rio de Janeiro: Lumen Juris, 2016. p.110.
} 
Revista Eletrônica de Direito Processual - REDP.

Rio de Janeiro. Ano 13. Volume 20. Número 1. Janeiro a Abril de 2019

Periódico Quadrimestral da Pós-Graduação Stricto Sensu em Direito Processual da UERJ

Patrono: José Carlos Barbosa Moreira (in mem.). ISSN 1982-7636. pp. 182-215

www.redp.uerj.br

Dos 9 processos analisados em 2016, em 7 as hipóteses dos artigos 355, I e 311,

II, ambos do CPC, coincidiram, de forma que a tutela de evidência foi deferida no mesmo momento processual em que houve o julgamento antecipado de mérito. Em um dos processos, a tutela de evidência foi indeferida e o juiz apenas proferiu sentença conforme o estado do processo, razão pela qual a decisão não serviu aos propósitos da pesquisa. Portanto, apenas uma das decisões concedeu exclusivamente a tutela de evidência sem que houvesse o julgamento antecipado de mérito. Isso significa que, no ano de 2016, do total de processos que deferiram a tutela de evidência (8), em quase $89 \%$ houve a sobreposição das hipóteses de incidência dos institutos processuais analisados.

GRÁFICO 1 - PERCENTUAL DE DECISÕES QUE APLICAM A TUTELA DE EVIDÊNCIA CONCOMITANTEMENTE AO JULGAMENTO ANTECIPADO DE MÉRITO NO ANO DE 2016

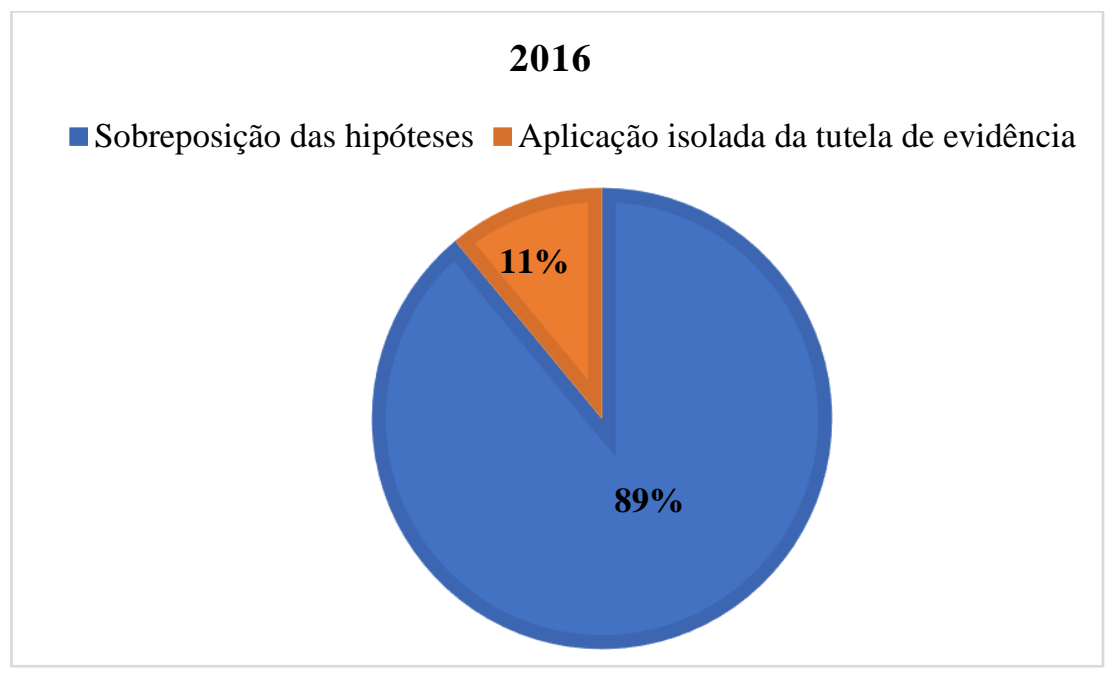

Dos 14 processos verificados em 2017, em 6 houve julgamento antecipado de mérito concomitantemente com a concessão da tutela de evidência, com fulcro no inciso II do art. 311 do CPC. Em apenas um processo, ocorreu exclusivamente o deferimento da tutela de evidência, de forma liminar. Um dos processos não versava sobre tutela de evidência e 6 processos foram julgados improcedentes ou indeferiram a tutela de evidência. Isso significa que, em quase $86 \%$ dos processos investigados em que foi concedida a tutela de evidência (7 do total de 14), houve o julgamento antecipado de mérito simultaneamente, indicando a ocorrência do fenômeno esperado. 
Revista Eletrônica de Direito Processual - REDP.

Rio de Janeiro. Ano 13. Volume 20. Número 1. Janeiro a Abril de 2019

Periódico Quadrimestral da Pós-Graduação Stricto Sensu em Direito Processual da UERJ

Patrono: José Carlos Barbosa Moreira (in mem.). ISSN 1982-7636. pp. 182-215

www.redp.uerj.br

GRÁFICO 2 - PERCENTUAL DE DECISÕES QUE APLICAM A TUTELA DE EVIDÊNCIA CONCOMITANTEMENTE AO JULGAMENTO ANTECIPADO DE MÉRITO NO ANO DE 2017

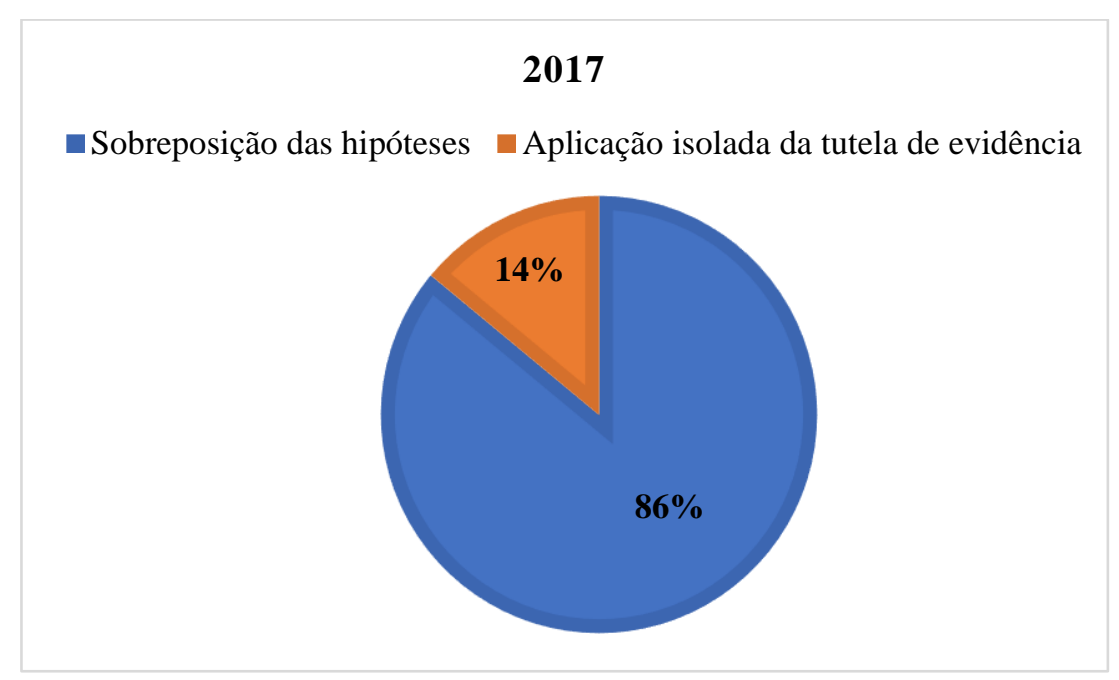

GRÁFICO 3 - APLICAÇÃO DA TUTELA DE EVIDÊNCIA EM 2016 E 2017 
Revista Eletrônica de Direito Processual - REDP.

Rio de Janeiro. Ano 13. Volume 20. Número 1. Janeiro a Abril de 2019

Periódico Quadrimestral da Pós-Graduação Stricto Sensu em Direito Processual da UERJ

Patrono: José Carlos Barbosa Moreira (in mem.). ISSN 1982-7636. pp. 182-215

www.redp.uerj.br

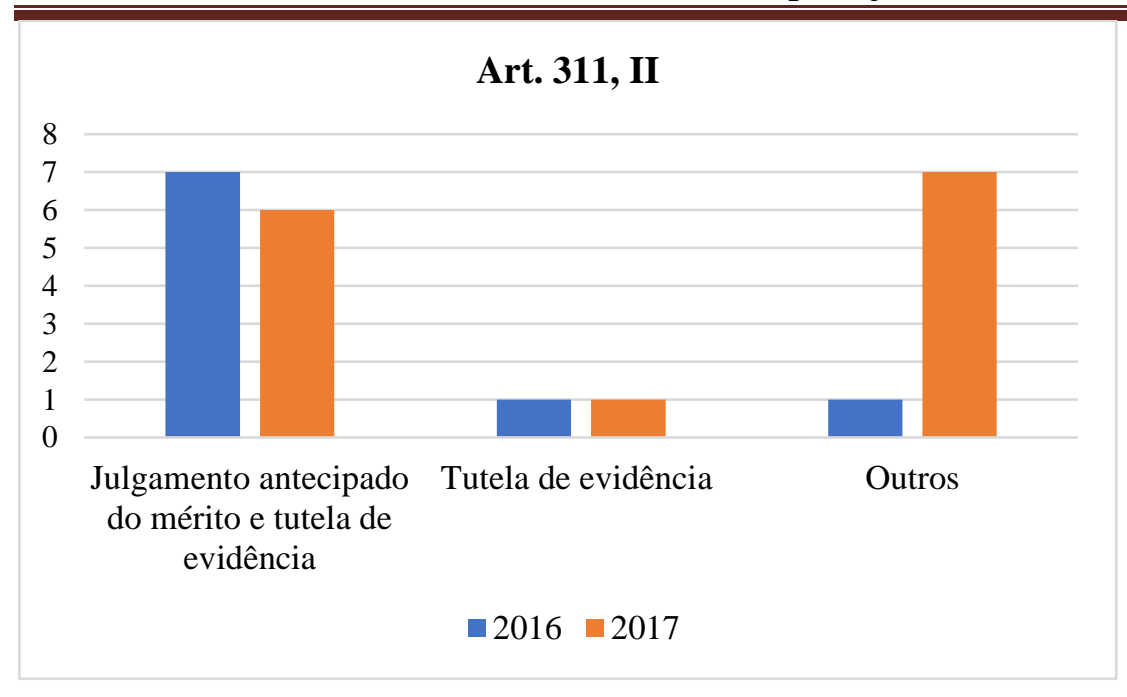

No entanto, nesse caso, a utilidade prática da tutela de evidência é maior do que a verificada no inciso IV e, portanto, a coincidência de aplicação dos institutos não fica adstrita a atingir os efeitos suspensivos de eventual recurso, porque é possível a concessão liminar da tutela de evidência. Dessa forma, enquanto o julgamento antecipado de mérito apenas pode ocorrer após a manifestação do réu nos autos, salvo em caso de revelia, na hipótese do art. 311, II do CPC, é possível atribuir o bem da vida à parte que possui o direito evidente antes mesmo da citação do réu, apresentando, portanto, uma vantagem processual em relação ao instituto do art. 355 , I do CPC, do ponto de vista da celeridade.

A possibilidade de concessão liminar, no entanto, não se exime de críticas. Isso porque, frequentemente, existe, na aplicação dos precedentes e na seleção dos julgados, o chamado conformation bias, no qual o sujeito processual (quer a parte interessada, quer o juiz) busca o julgado que confirmará a tese previamente escolhida e não o contrário.

Considerando a existência desse desvio na aplicação dos precedentes, a concessão da tutela de evidência exclusivamente com base na manifestação do autor que seleciona julgados que confirmem seus interesses, pode prejudicar o réu que não tiver a oportunidade de demonstrar a aplicação ou o afastamento do precedente em relação ao seu caso concreto $^{10}$.

10 PEREIRA, Alexandre Ferrer Silva. A efetividade da Tutela Antecipada de Evidência no Estado Democrático de Direito. Rio de Janeiro: Lumen Juris, 2016. p.130-132. 
Revista Eletrônica de Direito Processual - REDP.

Rio de Janeiro. Ano 13. Volume 20. Número 1. Janeiro a Abril de 2019

Periódico Quadrimestral da Pós-Graduação Stricto Sensu em Direito Processual da UERJ

Patrono: José Carlos Barbosa Moreira (in mem.). ISSN 1982-7636. pp. 182-215

www.redp.uerj.br

\section{TUTELA DE EVIDÊNCIA BASEADA NO DIREITO DO DEPOSITANTE (INCISO III)}

A fim de se verificar a aplicabilidade deste inciso, foram pesquisadas as decisões proferidas antes e depois da vigência do Código de Processo Civil pelo Tribunal de Justiça do Estado de São Paulo. Este é o único inciso que permite uma análise comparativa, por ser a hipótese de aplicação mais restrita. Por isso, a investigação, nesse caso, é feita nestes moldes.

Para tanto, nos processos pesquisados no período anterior à vigência do Código de Processo Civil de 2015, foi verificado o tempo transcorrido entre a distribuição do processo e o arquivamento do processo que colocava fim à fase de execução, quando o autor poderia obter o bem da vida, apurando-se, quando possível, a causa da demora constatada e identificando se esta poderia ser solucionada pela introdução da hipótese do inciso III do art. 311.

Para o período a partir de 2016, foram analisados os processos que deferiram a tutela de evidência com fundamento no dispositivo investigado, a fim de se verificar se há a efetiva aplicação desse instituto nas hipóteses contempladas pelo inciso III e se, atualmente, as decisões conseguem solucionar uma quantidade considerável de processos com base na tutela de evidência.

Em primeiro lugar, para a análise dos julgados proferidos antes da vigência do CPC/2015, foram consultadas as decisões de primeira instância do Tribunal de Justiça do Estado de São Paulo proferidas no ano de 2014. Não foi escolhido o ano de 2015 para a análise, pois, à época, o novo código já havia sido aprovado e promulgado, mas ainda se encontrava em vacatio legis, de modo que, ao pesquisar o ano de 2014, o objetivo foi evitar o período de transição legislativa e, assim, obter um resultado mais puro e preciso sobre o que se pretende demonstrar.

Com isso, foram consultadas as decisões de primeira instância do Tribunal de Justiça do Estado de São Paulo de 01 de janeiro a 31 de dezembro, que versassem sobre a matéria hoje disciplinada inciso III do art.311.

Para essa análise, em primeiro lugar foram usados como parâmetros da consulta, as expressões "contrato de depósito" e "entrega da coisa" no campo "Pesquisa Livre", filtrando processos que estivessem identificados na classe de "Processo Cível e do Trabalho" e nos assuntos "Inadimplemento" e "Depósito". Nessa pesquisa foram encontrados cinco 
Revista Eletrônica de Direito Processual - REDP.

Rio de Janeiro. Ano 13. Volume 20. Número 1. Janeiro a Abril de 2019

Periódico Quadrimestral da Pós-Graduação Stricto Sensu em Direito Processual da UERJ

Patrono: José Carlos Barbosa Moreira (in mem.). ISSN 1982-7636. pp. 182-215

www.redp.uerj.br

resultados, todos atinentes a contratos de alienação fiduciária que pretendiam a devolução da coisa através de uma ação de depósito: os processos de números 001078403.2008.8.26.0084, 0015798-85.2011.8.26.0302, 0000785-89.2009.8.26.0666, 011239747.2010.8.26.0100 e 0000559-52.2009.8.26.0127.

Em razão do pequeno número de processos retornados pelo sistema, o filtro de assuntos foi excluído, a fim de ampliar o número de resultados e obter uma verificação mais abrangente do assunto.

Nesses termos de pesquisa, dos 16 resultados retornados, apenas 5 puderam ser analisados, pois aos demais não poderia ser aplicada a hipótese do inciso III do art. 311. Isso porque os 11 processos descartados não têm como objeto um contrato de depósito, mas o reconhecimento do dever de depósito e guarda pelo juiz em razão de furtos praticados no interior de estabelecimentos, sobretudo, furtos de veículos em estacionamentos, o que afasta a aplicação do inciso III pela ausência de um depósito convencional. Além disso, o pedido aduzido pelas partes autoras referia-se à indenização pela perda da coisa e não pedido reipersecutório para entrega da coisa como exige o dispositivo. Por outro lado, os 5 demais processos analisados também se referem a ações de depósito ajuizadas com fundamento em contratos de alienação fiduciária: os processos de números 0158533-76.2008.8.26.0002, 0016200-13.2013.8.26.0007, 0006664-33.2012.8.26.0291, 0004243-17.2009.8.26.0666 e 0000559-52.2009.8.26.0127.

Ainda no intuito de ampliar o número de resultados obtidos, alterando os parâmetros da consulta para as expressões "contrato de depósito" e "ação de depósito" no campo "Pesquisa Livre" e filtrando processos que estivessem identificados na classe de "Processo Cível e do Trabalho" e nos assuntos "Inadimplemento" e "Depósito", foram encontrados 9 registros, sendo dois já analisados na pesquisa anterior, de forma que apenas os 7 restantes foram verificados: os processos de números 0030385-74.2007.8.26.0554, 0008576-56.2011.8.26.0564, 0424440-98.2009.8.26.0577, 0130466-29.2007.8.26.0005, 0010823-35.2008.8.26.0428, 0004262-63.2006.8.26.0428 e 0005827-77.2010.8.26.0022 .

Os resultados podem ser observados de forma mais detalhada na tabela a seguir, que retrata o tempo, em meses, da data de distribuição do processo à data de trânsito em julgado ou à data da decisão que determinou o cumprimento de sentença de cada processo, bem como o período entre a data da distribuição do processo e o seu arquivamento definitivo, com a satisfação do direito da parte por meio do fim da fase de execução. Ressalta-se que 
Revista Eletrônica de Direito Processual - REDP.

Rio de Janeiro. Ano 13. Volume 20. Número 1. Janeiro a Abril de 2019

Periódico Quadrimestral da Pós-Graduação Stricto Sensu em Direito Processual da UERJ

Patrono: José Carlos Barbosa Moreira (in mem.). ISSN 1982-7636. pp. 182-215

www.redp.uerj.br

não foi possível identificar, em todos os processos, a data do trânsito em julgado da decisão, em razão das limitações existentes na pesquisa em base de dados eletrônicas. Por isso, foi escolhida a data mais próxima a este ato, a saber, o momento em que foi determinado o cumprimento da sentença.

Além disso, quanto ao momento de arquivamento do processo, retratado na quinta coluna da tabela, é importante notar que poucos foram os processos que, na data da pesquisa (19 de junho de 2018), haviam logrado êxito em atribuir o bem da vida ao titular do direito. Como se nota, apenas 3 dos 17 processos foram definitivamente arquivados, com o fim da fase de execução e, consequentemente, efetivaram o direito da parte por meio da obtenção do bem da vida. Nos demais casos, a sigla “A.P.” indica o arquivamento provisório do processo por ter a execução se frustrado, seja em razão de os bens não terem sido localizados, seja em virtude de o exequente não ter tomado as providências necessárias à continuidade da execução, conforme especificado nos dados da tabela.

Muitos processos ainda não haviam sido concluídos na data da pesquisa, apesar do início da fase de execução, e estão indicados como processos "em curso".

TABELA 1 - TEMPO DE TRAMITAÇÃO DOS PROCESSOS (EM MESES) 
Revista Eletrônica de Direito Processual - REDP.

Rio de Janeiro. Ano 13. Volume 20. Número 1. Janeiro a Abril de 2019

Periódico Quadrimestral da Pós-Graduação Stricto Sensu em Direito Processual da UERJ

Patrono: José Carlos Barbosa Moreira (in mem.). ISSN 1982-7636. pp. 182-215

www.redp.uerj.br

\begin{tabular}{|c|c|c|c|c|c|}
\hline Processo & Data de distribuição do processo & Data de trânsito em julgado ou cumprimento de sentença & Período & Arquivamento definitivo & Período \\
\hline $\begin{array}{c}\text { No 0010784-03.2008.8.26.0084 } \\
4^{2} \text { vara de Campinas }\end{array}$ & $11 / 08 / 2008$ & $03 / 07 / 2015$ & 82 & 09/03/2018 & 114 \\
\hline $\begin{array}{c}\text { No 0015798-85.2011.8.26.0302 } \\
1^{2} \text { vara de Jaú }\end{array}$ & 03/10/2011 & 01/07/2015 & 44 & A.P. (bens não localizados) & - \\
\hline $\begin{array}{l}\text { No }^{\circ} 0000785-89.2009 .8 .26 .0666 \\
\text { Vara única de Mogi Mirim }\end{array}$ & $04 / 03 / 2009$ & $20 / 07 / 2015$ & 76 & $20 / 07 / 2015$ & 76 \\
\hline $\begin{array}{c}N^{\circ} 0112397-47.2010 .8 .26 .0100 \\
31^{2} \text { vara de São Paulo }\end{array}$ & 19/02/2010 & $12 / 01 / 2015$ & 58 & A.P. (sem manifestação do exequente) & - \\
\hline $\begin{array}{c}N^{\circ} 0000559-52.2009 .8 .26 .0127 \\
3^{2} \text { vara de Carapicuiba }\end{array}$ & $16 / 01 / 2009$ & 26/09/2014 & 68 & A.P. (sem manifestação do exequente) & - \\
\hline $\begin{array}{c}N^{\circ} 0030385-74.2007 .8 .26 .0554 \\
9^{2} \text { vara de Santo André }\end{array}$ & 07/08/2008 & $15 / 07 / 2017$ & 107 & $13 / 03 / 2018$ & 115 \\
\hline $\begin{array}{c}N^{\circ} 0008576-56.2011 .8 .26 .0564 \\
7^{2} \text { vara de São Bernardo do } \\
\text { Campo }\end{array}$ & 03/03/2011 & $28 / 05 / 2015$ & 50 & A.P. (sem bens penhoráveis) & - \\
\hline $\begin{array}{c}\mathrm{N}^{\circ} 0424440-98.2009 .8 .26 .0577 \\
6^{2} \text { vara de São José dos } \\
\text { Campos }\end{array}$ & 20/02/2009 & $26 / 11 / 2016$ & 93 & $14 / 04 / 2018$ & 109 \\
\hline $\begin{array}{l}N^{\circ} 0130466-29.2007 .8 .26 .0005 \\
4^{2} \text { vara civel de São Paulo }\end{array}$ & $19 / 12 / 2007$ & $11 / 12 / 2015$ & 95 & A.P. (sem bens penhoráveis) & - \\
\hline $\begin{array}{c}\mathrm{N}^{\circ} 0010823-35.2008 .8 .26 .0428 \\
2^{2} \text { vara de Campinas }\end{array}$ & $18 / 12 / 2008$ & 07/10/2014 & 69 & A.P. (sem bens penhoráveis) & - \\
\hline $\begin{array}{c}N^{\circ} 0004262-63.2006 .8 .26 .0428 \\
2^{2} \text { vara de Campinas }\end{array}$ & $28 / 06 / 2006$ & 06/10/2014 & 99 & Em curso & - \\
\hline $\begin{array}{c}\text { No 0005827-77.2010.8.26.0022 } \\
1^{2} \text { vara de Amparo }\end{array}$ & $27 / 10 / 2010$ & $10 / 04 / 2014$ & 41 & Em curso & - \\
\hline $\begin{array}{c}\mathrm{N}^{0} 01585333-76.2008 .8 .26 .0002 \\
5^{\mathbf{2}} \text { vara do foro regional de } \\
\text { Santo Amaro }\end{array}$ & $16 / 10 / 2008$ & 24/06/2015 & so & Em curso & - \\
\hline $\begin{array}{c}N^{\circ} 0016200-13.2013 .8 .26 .0007 \\
3^{2} \text { vara civel do foro regional } \\
\text { de Itaquera }\end{array}$ & $25 / 04 / 2013$ & $11 / 11 / 2014$ & 18 & A.P. (sem bens penhoráveis) & - \\
\hline $\begin{array}{c}\mathrm{N}^{\circ} 0006664-33.2012 .8 .26 .0291 \\
2^{2} \text { vara de Jaboticabal }\end{array}$ & 28/06/2012 & 27/06/2014 & 23 & Em curso & - \\
\hline $\begin{array}{l}\text { No 0004243-17.2009.8.26.0666 } \\
\text { vara única de Artur Nogueira }\end{array}$ & 24/07/2009 & 12/09/2014 & 61 & A.P. (sem manifestação do exequente) & - \\
\hline $\begin{array}{c}\mathrm{N}^{\circ} 0000559-52.2009 .8 .26 .0127 \\
3^{2} \text { vara de Carapicuiba }\end{array}$ & $16 / 01 / 2009$ & 26/09/2014 & 68 & A.P. (sem manifestação do exequente) & - \\
\hline 17 & & Tempo médio por processo: & 66,6 & & 104 \\
\hline
\end{tabular}

* Dados disponíveis em 29 de junho de 2018

O gráfico a seguir representa quantos dos processos lograram êxito em permitir ao titular do direito obter o bem da vida, com a conclusão da fase de execução, bem como quantos processos tiveram as execuções frustradas e quantos ainda estavam em curso na data da pesquisa. 


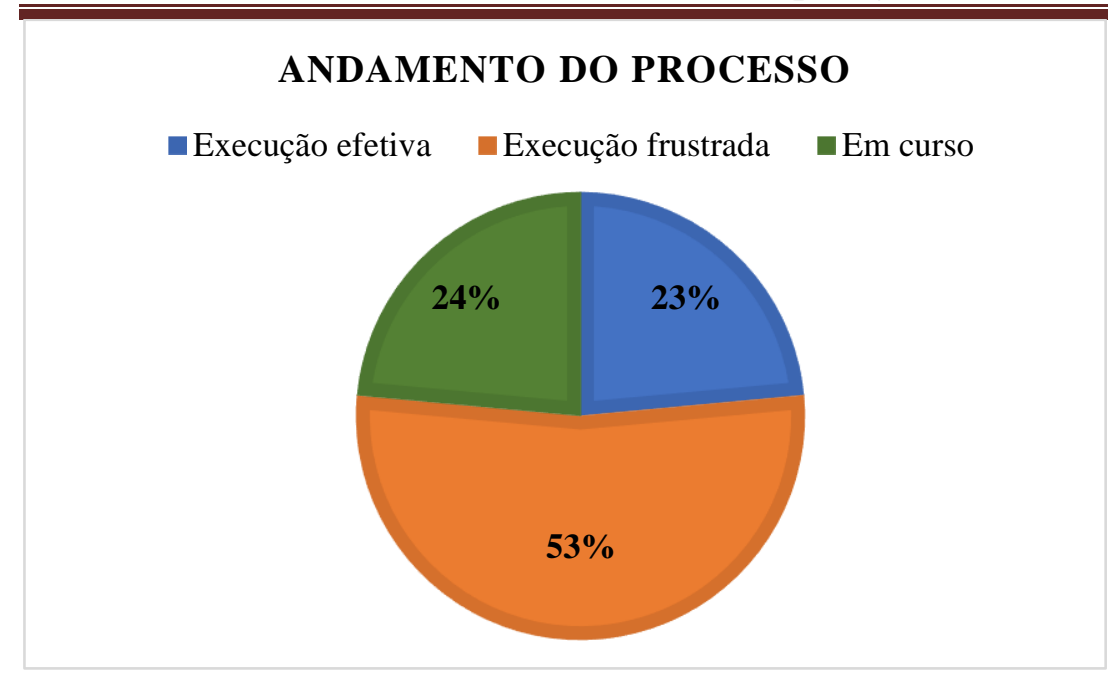

A análise dos dados colhidos a partir das 17 decisões de primeira instância permite concluir que, em 2014, ano anterior à reforma processual, as demandas tramitavam, em média, por 66,6 meses (um pouco mais de 5 anos e meio), até que houvesse o trânsito em julgado da sentença ou a fase de cumprimento da mesma, e por 104 meses (um pouco mais de 8 anos e meio) até o fim da fase de execução, momento em que, finalmente, o autor poderia ver seu direito tutelado e obter o bem da vida perseguido.

No entanto, a partir da leitura aprofundada de cada decisão, foi possível constatar que, em 14 desses processos, o tempo de demora não poderia ser atribuído à ausência de um instrumento processual eficaz para atender às necessidades da causa. Isso porque essas decisões eram provenientes de uma ação prévia de busca e apreensão em alienação fiduciária que foi convertida em ação de depósito e muitos desses processos eram hipóteses de julgamento antecipado da lide, nos termos do revogado art. 330, I do CPC/73.

O problema da primeira constatação é que, nas ações de busca e apreensão, sempre era concedida liminar, sendo posteriormente convertidas em ação de depósito em razão da impossibilidade de se encontrar o bem litigioso. Trata-se de uma hipótese de tutela de evidência específica para os contratos de alienação fiduciária que já existia antes da vigência do CPC/2015, prevista no art. $3^{\circ}$ do Decreto-Lei $n^{\circ}$ 911/69, que permite a concessão da busca e apreensão do bem alienado fiduciariamente, de forma liminar, quando comprovada a mora, independentemente da demonstração de urgência.

Sendo assim, a demora do processo nesses casos não ocorria pela falta de institutos de celeridade que contemplassem essa situação, mas em razão de um problema 
Revista Eletrônica de Direito Processual - REDP.

Rio de Janeiro. Ano 13. Volume 20. Número 1. Janeiro a Abril de 2019

Periódico Quadrimestral da Pós-Graduação Stricto Sensu em Direito Processual da UERJ

Patrono: José Carlos Barbosa Moreira (in mem.). ISSN 1982-7636. pp. 182-215

www.redp.uerj.br

que não pode ser solucionado pela introdução do inciso III do art. 311 no sistema, mesmo porque já havia a previsão da tutela de evidência liminar para os casos de alienação fiduciária. O problema da efetivação da tutela e da atribuição do bem da vida à parte que tinha o direito evidente, nessas situações, era a dificuldade de localização dos bens perseguidos, muitas vezes em razão de ocultação proposital do réu. Tanto o é que, em nenhum dos processos verificados, o bem litigioso foi encontrado por meio da busca e apreensão liminar e, em diversos deles, tampouco ao fim da fase de execução foi possível encontrar bens penhoráveis, de modo que a satisfação do direito da parte restou completamente frustrada.

Isso pode ser visualizado na tabela a seguir, que indica, em dias, o tempo decorrido entre a distribuição do processo e o deferimento da busca e apreensão liminar, esclarecendo que, caso o bem fosse encontrado, a parte obteria o bem da vida, em regra, dentro de apenas alguns dias após o ajuizamento da ação. Cabe a observação, porém, de que a informação da data em que houve a concessão da liminar não estava disponível em dois dos processos, por terem origem em vara distinta da qual tramitava a ação de depósito.

\section{TABELA 2 - CONCESSÃO DA BUSCA E APREENSÃO LIMINAR (EM DIAS)}

\begin{tabular}{cccc} 
Número do Processo & Data de distribuição do processo & Data de concessão da busca e apreensão liminar & Período \\
\hline $0010784-03.2008 .8 .26 .0084$ & $11 / 08 / 2008$ & sem informação & - \\
$0015798-85.2011 .8 .26 .0302$ & $03 / 10 / 2011$ & $04 / 10 / 2011$ & 1 \\
$0000785-89.2009 .8 .26 .0666$ & $04 / 03 / 2009$ & $13 / 03 / 2009$ & 9 \\
$0112397-47.2010 .8 .26 .0100$ & $19 / 02 / 2010$ & $23 / 02 / 2010$ & 4 \\
$0000559-52.2009 .8 .26 .0127$ & $16 / 01 / 2009$ & $28 / 01 / 2009$ & 12 \\
$0030385-74.2007 .8 .26 .0554$ & $07 / 08 / 2008$ & sem informação & - \\
$0008576-56.2011 .8 .26 .0564$ & $03 / 03 / 2011$ & $13 / 04 / 2011$ & 41 \\
$0130466-29.2007 .8 .26 .0005$ & $19 / 12 / 2007$ & $13 / 12 / 2008$ & 360 \\
$0005827-77.2010 .8 .26 .0022$ & $27 / 10 / 2010$ & $03 / 11 / 2010$ & 7 \\
$0158533-76.2008 .8 .26 .0002$ & $16 / 10 / 2008$ & $21 / 10 / 2008$ & 5 \\
$0016200-13.2013 .8 .26 .0007$ & $25 / 04 / 2013$ & $30 / 04 / 2013$ & 5 \\
$0006664-33.2012 .8 .26 .0291$ & $28 / 06 / 2012$ & $03 / 07 / 2012$ & $12 / 08 / 2009$ \\
$0004243-17.2009 .8 .26 .0666$ & $24 / 07 / 2009$ & $28 / 01 / 2009$ & 5 \\
$0000559-52.2009 .8 .26 .0127$ & $16 / 01 / 2009$ & Tempo médio por processo: & 19 \\
\hline 14 & & 40,0 \\
\hline
\end{tabular}

Apesar de, em regra, a medida liminar ser deferida em alguns dias, um dos processos ( $\mathrm{n}^{\circ}$ 0130466-29.2007.8.26.0005, que indica o período de 360 dias) exorbitou o tempo médio encontrado nos demais processos e, a partir da análise das informações constantes do sistema eletrônico, mesmo que insuficientes, tudo indica que a demora, nesse 
Revista Eletrônica de Direito Processual - REDP.

Rio de Janeiro. Ano 13. Volume 20. Número 1. Janeiro a Abril de 2019

Periódico Quadrimestral da Pós-Graduação Stricto Sensu em Direito Processual da UERJ

Patrono: José Carlos Barbosa Moreira (in mem.). ISSN 1982-7636. pp. 182-215

www.redp.uerj.br

caso, ocorreu em virtude das chamadas etapas mortas, relativas a períodos de total inatividade processual.

Também porque o bem não era encontrado é que, apesar do reconhecimento do direito da parte e da concessão de busca e apreensão liminar, nos processos analisados no ano de 2014, o cálculo do tempo para que a parte obtivesse o bem da vida não teve como termo final o momento em que o juiz deferia a tutela de evidência, mas sim o momento em que havia o fim da fase de execução e o arquivamento definitivo do processo, ocasião em que era possível satisfazer a pretensão do titular do direito reconhecido.

Importante destacar, ainda, que, uma vez convertida a busca e apreensão em ação de depósito, o juiz confirmava os termos da decisão liminar, dando provimento ao pedido da parte, no sentido de determinar a entrega do bem ou o pagamento em dinheiro no montante equivalente, sob pena de execução judicial. No entanto, em alguns processos, o bem pretendido sequer estava em posse do devedor ou não havia sobrevivido ao processo, razão pela qual, nesses casos, a execução forçada também não se prestava à tutela específica da pretensão da parte e tampouco à adjudicação do bem da vida pretendido, uma vez que à tutela jurisdicional apenas restava se esgotar na substituição pelo equivalente em dinheiro.

É bem verdade que, à época, a ação de depósito tramitava pelo rito especial, que, no passado, garantia, inclusive, a prisão do depositário infiel, como é notado em alguns dos casos analisados, medida considerada inconstitucional atualmente pela súmula vinculante $\mathrm{n}^{\circ}$ 25 do Supremo Tribunal Federal. Hoje, a referida ação tramita pelo rito comum, de forma que, de fato, goza de menor coercitividade, o que, equivocadamente, permitiria concluir que a introdução da tutela de evidência conferiria maior efetividade à decisão, na medida em que, se preenchidos os requisitos previstos no inciso III, do art. 311, o juiz expedirá o mandado de busca e apreensão, sob pena de multa.

No entanto, como dito, essa medida já podia e era atribuída em razão da existência da tutela de evidência nos casos de alienação fiduciária, o que acaba por absorver os impactos do inciso III do art. 311 do CPC. Isso porque a grande maioria dos processos trata dessa matéria, que é atendida por norma especial, já existente à época do antigo CPC. Isso é confirmado, especialmente, pelo fato de, na pesquisa, terem sido encontrados tão poucos processos que tratassem de situações de contrato puro de depósito, nos quais fosse perseguida a entrega da coisa, o que acaba por mitigar a utilidade prática do inciso III. 
Revista Eletrônica de Direito Processual - REDP.

Rio de Janeiro. Ano 13. Volume 20. Número 1. Janeiro a Abril de 2019

Periódico Quadrimestral da Pós-Graduação Stricto Sensu em Direito Processual da UERJ

Patrono: José Carlos Barbosa Moreira (in mem.). ISSN 1982-7636. pp. 182-215

www.redp.uerj.br

Além disso, quanto à segunda constatação, nos casos em que havia o julgamento

antecipado do mérito, o deferimento do bem da vida ao efetivo titular também se dava em momento processual anterior, pois trata-se de instituto também introduzido com o intuito de agilizar o provimento do processo. Com isso, o magistrado entendia que o direito já estava suficientemente provado pelos documentos acostados e dispensava a fase de produção probatória.

Quanto aos 3 processos que não versavam sobre alienação fiduciária e, consequentemente, não se enquadravam em hipótese para a qual já existia tutela de evidência, importa identificar se a eles teria sido possível aplicar o inciso III do art. 311 caso tivessem tramitado na vigência do CPC/15.

Para verificar o cumprimento ou não do art. 311, III do CPC foram estabelecidos 3 critérios objetivos, extraídos diretamente do texto legal, de forma que, para que a tutela de evidência pudesse ser aplicada, deveriam estar presentes, simultaneamente: 1) pedido reipersecutório; 2) fundamento em contrato de depósito e 3) suficiência de provas nos autos.

Em primeiro lugar, a ação de número 0424440-98.2009.8.26.0577 foi ajuizada por Nacional Gás Butano Distribuidora em face de José Sebastião de Oliveira SJCamposME, alegando que celebrou contrato de depósito com o réu, mas este não restituiu os bens móveis descritos. Na referida ação, o juiz julgou antecipadamente o mérito, entendendo que a questão de mérito prescindia de produção de prova em audiência. Sendo assim, a sentença proferida indica que está preenchido o requisito de que haja prova documental adequada do contrato de depósito. Além disso, o autor aduziu pedido reipersecutório, já que pretendeu, na exordial, a restituição do bem, buscando especificamente a entrega da coisa, conforme exigido pelo art. 311 do CPC. Ao final, o juiz considerou procedente a ação de depósito e expediu mandado para entrega. Portanto, pelo que se depreende da análise da decisão e nos termos dos critérios estabelecidos, há indícios muito fortes de que, ao caso, seria possível aplicar a tutela de evidência com fundamento no atual inciso III.

A partir disso, é viável, ainda, mensurar o que a aplicação desse instituto significaria para a parte que teve seu direito tutelado, no que diz respeito ao tempo de obtenção do bem da vida.

No caso, considerando a possibilidade de deferimento da tutela pretendida antes mesmo da citação do réu, por tratar-se de hipótese que autoriza a entrega da coisa de forma liminar, a ação que tramitou por 109 meses (cerca de 9 anos) até que o autor pudesse 
Revista Eletrônica de Direito Processual - REDP.

Rio de Janeiro. Ano 13. Volume 20. Número 1. Janeiro a Abril de 2019

Periódico Quadrimestral da Pós-Graduação Stricto Sensu em Direito Processual da UERJ

Patrono: José Carlos Barbosa Moreira (in mem.). ISSN 1982-7636. pp. 182-215

www.redp.uerj.br

obter o bem da vida, poderia tê-lo concedido ao autor em menos de 13 meses (um pouco mais de 1 ano), pois o processo foi distribuído em 20 de fevereiro de 2009 e o primeiro ato judicial registrado no sistema foi em 16 de abril de 2010, que determinava a manifestação do autor sobre a certidão do Oficial de Justiça, em razão de o réu não ter sido encontrado.

De fato, a previsão não consegue ser fiel à realidade, porque bancos de dados eletrônicos enfrentam deficiência de dados e, assim como na situação, não há informações suficientes que permitam precisar o momento em que houve a citação do réu para oferecer contestação. No entanto, é possível presumir, a partir dos dados apresentados na Tabela 2 e da natureza do ato proferido, que o período de 13 meses para o deferimento da liminar é até exagerado, uma vez que, como detectado, as liminares normalmente são deferidas em apenas alguns dias.

Em segundo lugar, o processo de número 0010823-35.2008.8.26.0428 se refere a ação ajuizada pela mesma empresa de Gás Butano, em face de Jurandir de Oliveira São Sebastião da Gama ME, aduzindo que celebrou com o réu contrato de depósito de 200 botijões de GLP por prazo indeterminado, até que houvesse a rescisão do contrato, ocasião em que os bens não foram restituídos. Trata-se novamente, portanto, de pedido reipersecutório fundado em contrato de depósito. Também como na ação anterior, o juiz julgou antecipadamente o mérito, afirmando que a matéria independia da produção de outras provas. Ademais, segundo o magistrado, o contrato de depósito e a quantidade de produtos restaram incontestes nos autos ante a documentação trazida pelo autor. Dessa forma, estão preenchidos os 3 critérios estabelecidos para que haja a aplicação da tutela de evidência nessa situação.

Constatado isso, é possível estimar que a ação poderia ter atribuído o bem da vida ao titular do direito evidente em apenas 4 dias, pois a ação foi distribuída em 18 de dezembro de 2008 e em 22 de dezembro de 2008 foi proferido o primeiro despacho. No entanto, é relevante apontar que esse processo foi provisoriamente arquivado na fase de execução, por não terem sido identificados bens penhoráveis. Dessa forma, provavelmente, a concessão da liminar com fundamento no art. 311, III do CPC, que poderia ser aplicado ao caso, também restaria frustrada, havendo, mais uma vez, um obstáculo de caráter prático à satisfação do direito do autor.

Por fim, o processo de número 0004262-63.2006.8.26.0428 também versa sobre ação de depósito proposta pela mesma empresa em face de Odair del Mouro - ME, por meio 
Revista Eletrônica de Direito Processual - REDP.

Rio de Janeiro. Ano 13. Volume 20. Número 1. Janeiro a Abril de 2019

Periódico Quadrimestral da Pós-Graduação Stricto Sensu em Direito Processual da UERJ

Patrono: José Carlos Barbosa Moreira (in mem.). ISSN 1982-7636. pp. 182-215

www.redp.uerj.br

da qual novamente requereu a devolução de 2.080 botijões vazios que eram acondicionados pelo réu e que não foram restituídos quando houve a rescisão do contrato de depósito. Mais uma vez, houve por bem ao magistrado julgar antecipadamente o mérito, no qual o juiz entendeu pelo acolhimento do pedido, atestando que a prova documental acarreada nos autos não deixava qualquer dúvida quanto à responsabilidade do réu. Com isso, determinou ao requerido a devolução dos bens. Sendo assim, mais uma vez é possível concluir, pela verificação dos três critérios elencados, que a tutela de evidência poderia ter sido aplicada ao caso.

Dessa forma, a ação que tramitou por 99 meses (um pouco mais de 8 anos), contados da distribuição do processo, e que, no momento desta pesquisa, ainda estava em curso na fase de execução, poderia ter deferido o bem da vida pretendido, com fundamento no art. 311, III do CPC, em menos de 53 meses (quase 4 anos e meio), já que a distribuição do processo ocorreu em 28 de junho de 2006 e o primeiro ato registrado no sistema remonta a 01 de dezembro de 2010, quando foi proferido despacho que determinou a citação do réu por edital.

No processo analisado, não há qualquer informação anterior a essa data (01/12/2010) que permita uma melhor verificação do momento em que poderia ocorrer o deferimento da tutela de evidência, de forma que, mais uma vez, impende lembrar as limitações de uma pesquisa em banco de dados eletrônico, o que obsta uma estimativa mais precisa.

Essa análise permite concluir que a ampliação do rol do art. 311 pode não causar os impactos que dela se esperava, porque apresenta uma aplicação bastante restrita: dos 17 processos analisados, apenas 3 tinham por fundamento contrato de depósito que autorizava a incidência do art. 311, III do CPC, sendo que todos eles versavam sobre a mesma matéria e tinham o mesmo polo processual ativo e um deles, ao final, restou frustrado. Quanto aos outros 14 processos, o Judiciário já encontrava meios, na situação pesquisada, de contornar os problemas de morosidade processual, mas não era e ainda não é, mesmo com a introdução do art. 311 do CPC, capaz de driblar obstáculos que não são de cunho procedimental, mas prático.

Além disso, a partir dos dados coletados, é possível identificar que a dificuldade em se aplicar o inciso III do art. 311 pode decorrer das muitas especificações exigidas pelo dispositivo. Pela análise dos julgados e à luz do entendimento doutrinário sobre o tema, 
Revista Eletrônica de Direito Processual - REDP.

Rio de Janeiro. Ano 13. Volume 20. Número 1. Janeiro a Abril de 2019

Periódico Quadrimestral da Pós-Graduação Stricto Sensu em Direito Processual da UERJ

Patrono: José Carlos Barbosa Moreira (in mem.). ISSN 1982-7636. pp. 182-215

www.redp.uerj.br

constata-se que a lei exclui da aplicação da tutela de evidência justamente as condições em que a grande parte dos casos se desenvolve: 1) ações cujas pretensões não sejam a entrega da coisa, mas a indenização equivalente, ainda que haja um contrato de depósito e 2) ações cujo dever de depósito não decorre do contrato, mas de uma disposição legal ou da necessidade. É o que ocorre nos casos apontados de furto em estabelecimentos fechados, ainda que haja prova documental suficiente.

Por isso, a utilização do dispositivo fica restrita a alguns poucos casos que eventualmente aparecem nos tribunais atendendo aos requisitos exigidos. Adianta-se que isso fica claro nas pesquisas realizadas após a vigência do CPC, nas quais são muito poucos os resultados encontrados em que há o deferimento da tutela de evidência com fundamento no inciso III. Os dados também esclarecem que, mesmo quando a parte requer sua aplicação, os magistrados indeferem o pedido por faltarem os diversos requisitos exigidos.

É o que defendem alguns autores, ao colocarem a legislação como causa da morosidade do processo, informando que, apesar de o CPC ter passado por uma evolução científica muito grande nos últimos séculos, na prática, existem obstáculos que revelam que as normas são insuficientes e inadequadas para a agilidade e efetividade dos instrumentos processuais na solução das disputas ${ }^{11}$.

No entanto, não se pode ignorar que, por mais raros que sejam os casos que versem sobre a situação descrita no inciso III, o impacto da tutela de evidência no tempo que o titular do direito evidente precisa aguardar até a obtenção do bem da vida desejado é muito expressivo e, nesse sentido, cumpre muito bem o papel de inverter o ônus do tempo. Como visto, a parte que antes chegava a aguardar por mais de 8 anos até que houvesse a solução do litígio poderia obter o bem da vida, mediante expedição de ordem de entrega, em apenas alguns dias, com a introdução do instituto no art. 311 do CPC.

Por fim, um aspecto que merece atenção é que, nos casos de tutela de evidência em alienação fiduciária, prevista em norma especial, as ações analisadas mostram que não houve revogação de nenhuma das decisões proferidas em sede de cognição sumária. Isso permite verificar que, na prática, a evidência proposta pelo legislador efetivamente existe, indicando um baixo grau de falibilidade na concessão da medida liminar. A importância dessa constatação é que, ao assegurar a razoável duração do processo, a norma não sacrificou

\footnotetext{
${ }^{11}$ DUARTE, Ricardo Quass. O tempo inimigo no Processo Civil Brasileiro. São Paulo: LTr, 2009. p.128.
} 
Revista Eletrônica de Direito Processual - REDP.

Rio de Janeiro. Ano 13. Volume 20. Número 1. Janeiro a Abril de 2019

Periódico Quadrimestral da Pós-Graduação Stricto Sensu em Direito Processual da UERJ

Patrono: José Carlos Barbosa Moreira (in mem.). ISSN 1982-7636. pp. 182-215

www.redp.uerj.br

a segurança jurídica que legitimamente se espera do ordenamento, de forma que o legislador logrou êxito, quanto a esse ponto, na difícil tarefa de equilibrar e assegurar simultaneamente essas garantias constitucionais.

Caso, ao final da fase de conhecimento, houvesse um elevado número de decisões liminares revogadas, a celeridade do processo estaria prevalecendo de forma indevida sobre a segurança jurídica e não seria possível outra conclusão senão a de que o legislador teria insculpido hipótese de tutela de evidência que não guardava qualquer relação com a realidade jurídica. E, ressalte-se, a segurança jurídica ganha especial importância nos casos de tutela de evidência, pois não existe periculum in mora para qualquer das partes.

Concluída essa breve observação, passa-se à análise dos julgados proferidos após a vigência do CPC/2015. Para isso, foram consultadas as decisões de primeira e segunda instâncias do Tribunal de Justiça do Estado de São Paulo a partir de 18 de março de 2016 (data em que o CPC passou a vigorar) até 31 de dezembro 2017. Nesse período, diferentemente dos processos analisados em 2014, cujo objetivo era identificar a matéria discutida, foi pertinente pesquisar decisões em segunda instância, porque existe a tutela de evidência recursal, o que consta expressamente também do Enunciado 423 do VIII Fórum Permanente de Processualistas Civis.

Foi usada, como parâmetro da consulta, a expressão "art.311, III" no campo "Pesquisa Livre", sem qualquer outro filtro.

No ano de 2016, a busca, em primeira instância, resultou em dois processos: o processo de número 0008032-45.2007.8.26.0132, distribuído na $3^{\mathrm{a}}$ vara cível do foro de Catanduva e o processo de número 0017377-27.2013.8.26.0002, distribuído na 6 $6^{\text {a }}$ vara cível do foro regional de Santo Amaro.

No primeiro processo mencionado, houve ação de busca e apreensão com fundamento em contrato de alienação fiduciária convertida em ação de depósito, em razão de o bem não ter sido encontrado. No entanto, após a referida decisão, o juiz não apenas julgou antecipadamente o mérito, nos termos do art. 355, I do CPC, como ocorreu nos processos pesquisados no ano de 2014, como também aplicou a tutela de evidência prevista no inciso III do art. 311, expedindo-se desde logo mandado de entrega do bem sob pena de multa diária. No entanto, percebe-se que não existiu impacto no tempo do curso do processo, quando comparado com o tempo médio calculado nos processos mais antigos, uma vez que a ação foi distribuída em 18 de junho de 2007 e a tutela de evidência apenas foi deferida em 
Revista Eletrônica de Direito Processual - REDP.

Rio de Janeiro. Ano 13. Volume 20. Número 1. Janeiro a Abril de 2019

Periódico Quadrimestral da Pós-Graduação Stricto Sensu em Direito Processual da UERJ

Patrono: José Carlos Barbosa Moreira (in mem.). ISSN 1982-7636. pp. 182-215

www.redp.uerj.br

26 de agosto de 2016. A demora, no caso, possivelmente pode ser atribuída ao fato de que a ação foi distribuída e tramitou, por um tempo considerável, sob a vigência do $\mathrm{CPC} / 73$, que não trazia as hipóteses de tutela de evidência que constam expressamente no $\mathrm{CPC} / 15$. A partir da vigência do CPC em 2016, no entanto, a tutela de evidência foi deferida dentro de apenas alguns meses.

O segundo processo refere-se a uma ação de rescisão de contrato de compra e venda de negócio comercial cumulado com reintegração de posse de equipamentos e aparelhos de ginástica. $\mathrm{Na}$ decisão, o magistrado entendeu que o contrato estava suficientemente provado e que o débito não havia sido infirmado pelo réu. Dessa forma, a tutela de evidência foi aplicada com fundamento no inciso III do art. 311 do CPC para que a decisão fosse cumprida independentemente do trânsito em julgado, sob pena de multa diária.

Em 2017, os mesmos termos de busca não trouxeram qualquer resultado.

Na pesquisa dos tribunais de segunda instância, foram incluídos os mesmos termos de pesquisa, retornando 3 resultados no ano de 2016 e 8 resultados em 2017.

Dos 3 processos encontrados em 2016, um não se tratava do dispositivo do Código de Processo Civil, mas de artigo com mesma numeração presente em outra legislação.

Os outros dois processos, de números 2129320-16.2016.8.26.0000 e 212296235.2016.8.26.0000, dizem respeito a agravos de instrumento interpostos contra a decisão que indeferiu o pedido de tutela de evidência com fundamento no inciso III, em ação fundada em contrato de compra e venda com reserva de domínio. No entanto, em grau recursal, a decisão foi mantida, porque o tribunal entendeu não existir o contrato de depósito exigido pelo art. 311 do CPC. Os julgados explicaram que, na hipótese, caberia apenas a aplicação do inciso IV do dispositivo, que não poderia ser deferido liminarmente e, por isso, obstaram o provimento do recurso.

No ano de 2017, os mesmos parâmetros de pesquisa resultaram em 8 processos.

Três dos 8 processos não serão explicados. Dois por se tratarem de embargos de declaração, que, por não se prestarem ao reexame de questões de fato ou de direito, não servem para a análise. Outro, porque, a despeito de a decisão ter mencionado o art. 311, III do CPC, deferiu tutela de urgência, com fundamento no art. 300 do CPC. 
Revista Eletrônica de Direito Processual - REDP.

Rio de Janeiro. Ano 13. Volume 20. Número 1. Janeiro a Abril de 2019

Periódico Quadrimestral da Pós-Graduação Stricto Sensu em Direito Processual da UERJ

Patrono: José Carlos Barbosa Moreira (in mem.). ISSN 1982-7636. pp. 182-215

www.redp.uerj.br

Os processos de número 2150518-75.2017.8.26.0000 e 2058780-

06.2017.8.26.0000 também tratavam de pedido de tutela de evidência fundado em contrato de compra e venda com reserva de domínio, o qual restou rejeitado tanto em primeira instância quanto no agravo de instrumento julgado, por, novamente, não se tratar da espécie contratual exigida pelo inciso III.

O agravo de instrumento interposto no processo de número 217327041.2017.8.26.0000 resultou da irresignação da agravante em relação à decisão que indeferiu o pedido de tutela de evidência liminar para baixa da hipoteca de imóvel em ação de adjudicação compulsória. No entanto, o recurso também não foi provido.

No processo de número 2137310-24.2017.8.26.0000, também não foi dado provimento ao recurso de agravo de instrumento, diante do não preenchimento dos requisitos necessários à concessão da tutela de evidência para suspensão da inexigibilidade do ICMS sobre a Tarifa de Uso do Sistema de Distribuição - TUSD e a Tarifa de Uso do Sistema de Transmissão - TUST.

Por último, o agravo de instrumento do processo de número 222677311.2016.8.26.0000 foi o único que manteve a decisão de primeira instância que deferiu a tutela de evidência.

TABELA 3 - PROCESSOS FUNDADOS NO ART. 311, III DO CPC

\begin{tabular}{|c|c|c|c|c|c|}
\hline & & & 2016 & 2017 & Total \\
\hline \multirow[b]{2}{*}{$\begin{array}{l}\text { Número de processos encontrados em } 1^{2} \\
\text { instância }\end{array}$} & \multirow[b]{2}{*}{2} & $\begin{array}{l}\text { Número de processo que deferiram a tutela de evidência } \\
\text { com fundamento no art. } 311, \mathrm{III} \text { em } 1^{2} \text { instância }\end{array}$ & 2 & 0 & 2 \\
\hline & & $\begin{array}{l}\text { Número de processo que indeferiram a tutela de } \\
\text { evidência com fundamento no art. } 311 \text {, III em } 1^{2} \\
\text { instância }\end{array}$ & 0 & 0 & 0 \\
\hline \multirow{4}{*}{$\begin{array}{l}\text { Número de processos encontrados em } \\
\text { recursos }\end{array}$} & \multirow{3}{*}{11} & $\begin{array}{l}\text { Número de processo que deferiram a tutela de evidência } \\
\text { com fundamento no art. } 311 \text {, III em recursos }\end{array}$ & 0 & 1 & 1 \\
\hline & & $\begin{array}{l}\text { Número de processo que ideferiram a tutela de } \\
\text { evidência com fundamento no art. } 311 \text {, III em recursos }\end{array}$ & 2 & 4 & 6 \\
\hline & & Descartados & 1 & 3 & 4 \\
\hline & & $\begin{array}{l}\text { Total de processos que deferiram tutela de evidência } \\
\text { com fundamento no art. } 311 \text {, III, em primeira e em } \\
\text { segunda instância }\end{array}$ & & $23 \%$ & \\
\hline
\end{tabular}

Desconsiderando os processos descartados, tem-se: 

FULCRO NO ART. 311, III DO CPC

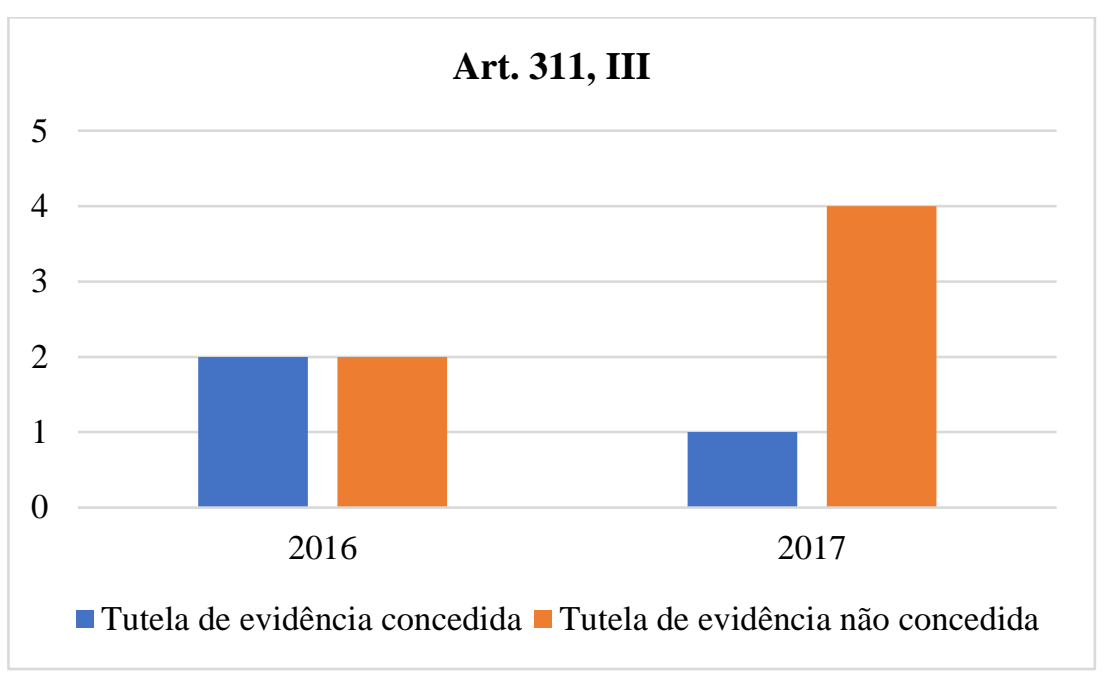

Percebe-se, como adiantado, que o número de processos que versaram sobre tutela de evidência com fundamento do inciso III do art. 311 foi muito pequeno e, dentre os resultados encontrados, vários pedidos foram indeferidos porque não satisfaziam os requisitos exigidos pela lei, de forma que não constituíam a hipótese contemplada pelo art. 311 do CPC.

Conforme representado na tabela, do total de 13 processos encontrados em primeira e em segunda instâncias, o que por si só informa uma quantidade muito pouco expressiva, apenas $23 \%$ efetivamente deferiram a tutela de evidência com fundamento no art. 311, III do CPC, ou seja, entenderam que estavam preenchidos os requisitos para sua concessão. Essa circunstância reforça a constatação firmada anteriormente, no sentido de que a aplicação prática do inciso III do art. 311 tem sido restrita e, portanto, a aplicabilidade e a efetividade desse dispositivo podem não ser tão amplas quanto o esperado. 
Revista Eletrônica de Direito Processual - REDP.

Rio de Janeiro. Ano 13. Volume 20. Número 1. Janeiro a Abril de 2019

Periódico Quadrimestral da Pós-Graduação Stricto Sensu em Direito Processual da UERJ

Patrono: José Carlos Barbosa Moreira (in mem.). ISSN 1982-7636. pp. 182-215

www.redp.uerj.br

GRÁFICO 6 - PERCENTUAL DE DECISÕES QUE DEFEREM A TUTELA DE EVIDÊNCIA COM FUNDAMENTO NO ART. 311, III DO CPC

\section{Concessão da tutela de evidência}

- Tutela de evidência concedida Tutela de evidência não concedida

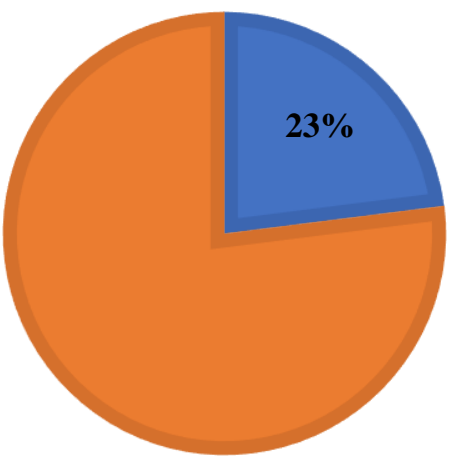

\section{TUTELA DE EVIDÊNCIA FUNDADA EM PROVA DOCUMENTAL (INCISO IV)}

Essa hipótese é a que mais se aproxima do julgamento antecipado do mérito, previsto no art. 355 do CPC, sobretudo porque este autoriza a dispensa da instrução probatória quando não houver a necessidade de produção de outras provas além das acostadas nos autos.

Assim, tal como verificado na aplicação do inciso II, na grande maioria dos casos contemplados pelo inciso IV do art. 311 do CPC, as hipóteses de aplicação da tutela de evidência e de julgamento antecipado do mérito também coincidem, de maneira que são utilizados concomitantemente, como forma de otimizar o tempo do processo ao se proferir uma decisão definitiva.

A aplicação isolada da tutela de evidência, portanto, é muito rara, justamente porque dificilmente fica visível quando a instrução probatória é suficiente e quando é apenas verossímil. Em outras palavras, o grau de comprovação do direito diferenciado pela doutrina e pelo legislador acaba sendo idêntico nos casos de tutela de evidência e de julgamento antecipado de mérito.

Por isso, há entendimentos de que a aplicação da tutela de evidência necessariamente implicaria na aplicação do julgamento antecipado de mérito, havendo uma 
Revista Eletrônica de Direito Processual - REDP.

Rio de Janeiro. Ano 13. Volume 20. Número 1. Janeiro a Abril de 2019

Periódico Quadrimestral da Pós-Graduação Stricto Sensu em Direito Processual da UERJ

Patrono: José Carlos Barbosa Moreira (in mem.). ISSN 1982-7636. pp. 182-215

www.redp.uerj.br

superposição dos dois institutos ${ }^{12}$, em razão da semelhança das hipóteses de aplicação do atual inciso IV do art. 311 e do revogado art. 330, reproduzido no atual art. 355, I do CPC.

Isso ocorre porque, caso os fatos já estejam demonstrados por prova documental e o réu não oponha prova que gere dúvida razoável, os fatos restarão incontroversos e provavelmente já será possível a dispensa da fase instrutória, autorizando, assim, também o julgamento antecipado de mérito ${ }^{13}$.

Essa constatação leva a crer que a aplicação do atual inciso IV pode se tornar confusa, pois as hipóteses são muito próximas e, nesse sentido, a aplicação prática desse dispositivo também poderia restar prejudicada pelo fato de, no passado, já se julgar antecipadamente o mérito, de modo que a tutela de evidência nesse caso se esvaziaria.

Afinal, como o inciso IV não pode ser concedido liminarmente, não tem o condão de atribuir o bem da vida à parte que tem o direito evidente em momento mais breve. Por isso, a aplicação isolada do julgamento antecipado do mérito mostra-se mais vantajosa que a aplicação isolada da tutela de evidência, porque ambos permitem o julgamento quando as provas colacionadas forem suficientes, mas o primeiro exprime decisão definitiva, proferida através de cognição exauriente, enquanto a segunda estabelece uma tutela provisória, deferida por cognição sumária.

Sendo assim, o julgamento antecipado de mérito, autorizado pela ausência de controvérsia da matéria, confere maior estabilidade ao processo ${ }^{14}$.

Por outro lado, a tutela de evidência pode se constituir um instrumento que, aliado ao julgamento antecipado de mérito, consegue atribuir maior efetividade no provimento do bem da vida à parte, pois a introdução dessa hipótese do art. 311 permite que, quando as provas dos autos forem suficientes, haja o cumprimento provisório da decisão ainda que não tenha ocorrido seu trânsito em julgado (art. 1.012, § $1^{\circ}, \mathrm{V}, \mathrm{CPC}$ ), efeito que o julgamento antecipado de mérito não produz. Assim, mostra-se muito útil ao bom andamento do processo que, ao mesmo tempo, o magistrado defira tutela de evidência e julgue antecipadamente o mérito, quando possível, pois, nesse caso, a decisão pode ser proferida já

\footnotetext{
12 PONTES, Daniel de Oliveira. A tutela de evidência no Novo Código de Processo Civil: uma gestão mais justa do tempo na relação processual, Revista de Processo, São Paulo, v. 261, ano 41, p.364, nov. 2016.

${ }^{13}$ RODRIGUES, Marco Antonio; RANGEL, Rafael Calmon. A tutela de evidência como técnica de atuação judicial, Revista de Processo, São Paulo, v. 271, ano 42, p.266-267, set. 2017.

${ }^{14}$ MITIDIERO, Daniel. Antecipação da Tutela: Da tutela cautelar à técnica antecipatória. 3. ed. São Paulo: Revista dos Tribunais, 2017. p.162.
} 
Revista Eletrônica de Direito Processual - REDP.

Rio de Janeiro. Ano 13. Volume 20. Número 1. Janeiro a Abril de 2019

Periódico Quadrimestral da Pós-Graduação Stricto Sensu em Direito Processual da UERJ

Patrono: José Carlos Barbosa Moreira (in mem.). ISSN 1982-7636. pp. 182-215

www.redp.uerj.br

de forma definitiva, e, ainda, serão evitados eventuais efeitos suspensivos de recurso, produzindo a decisão efeitos desde $\log \mathrm{o}^{15}$.

É o que se verifica na pesquisa dos julgados de $1^{\circ}$ grau do Tribunal de Justiça do

Estado de São Paulo, constatando-se que, de fato, esses dois institutos acabam sendo aplicados em conjunto, por assegurarem uma utilidade prática mais adequada e por, em muitos aspectos, terem incidência nas mesmas circunstâncias.

Quando, por meio do Portal de Serviços $e$-saj, no campo "Pesquisa Livre”, sem qualquer outro filtro de classe ou assunto, busca-se o termo "art. 311, IV", o sistema retorna, no ano de 2016, 72 processos, e, no ano de 2017, 176 processos.

Dos 72 processos relativos ao ano de 2016, 40 foram julgados antecipadamente e, concomitantemente, tiveram tutela de evidência deferida; enquanto em 30 deles foi deferida, exclusivamente, a tutela de evidência. Dois dos processos não tratavam da tutela de evidência, mas apenas mencionaram o dispositivo para fins argumentativos. Sendo assim, desconsiderando os processos em que não foi deferida a tutela de evidência, cerca de $57 \%$ dos processos analisados foram julgados conforme o estado do processo, com sentença prolatada sem fase instrutória, e utilizaram a tutela de evidência para permitir que a decisão produzisse efeitos imediatos.

GRÁFICO 7 - PERCENTUAL DE DECISÕES QUE APLICAM A TUTELA DE EVIDÊNCIA CONCOMITANTEMENTE AO JULGAMENTO ANTECIPADO DE MÉRITO NO ANO DE 2016

\footnotetext{
${ }^{15}$ RODRIGUES, Marco Antonio; RANGEL, Rafael Calmon. A tutela de evidência como técnica de atuação
} judicial, Revista de Processo, São Paulo, v. 271, ano 42, p.267, set. 2017. 
Revista Eletrônica de Direito Processual - REDP.

Rio de Janeiro. Ano 13. Volume 20. Número 1. Janeiro a Abril de 2019

Periódico Quadrimestral da Pós-Graduação Stricto Sensu em Direito Processual da UERJ

Patrono: José Carlos Barbosa Moreira (in mem.). ISSN 1982-7636. pp. 182-215

www.redp.uerj.br

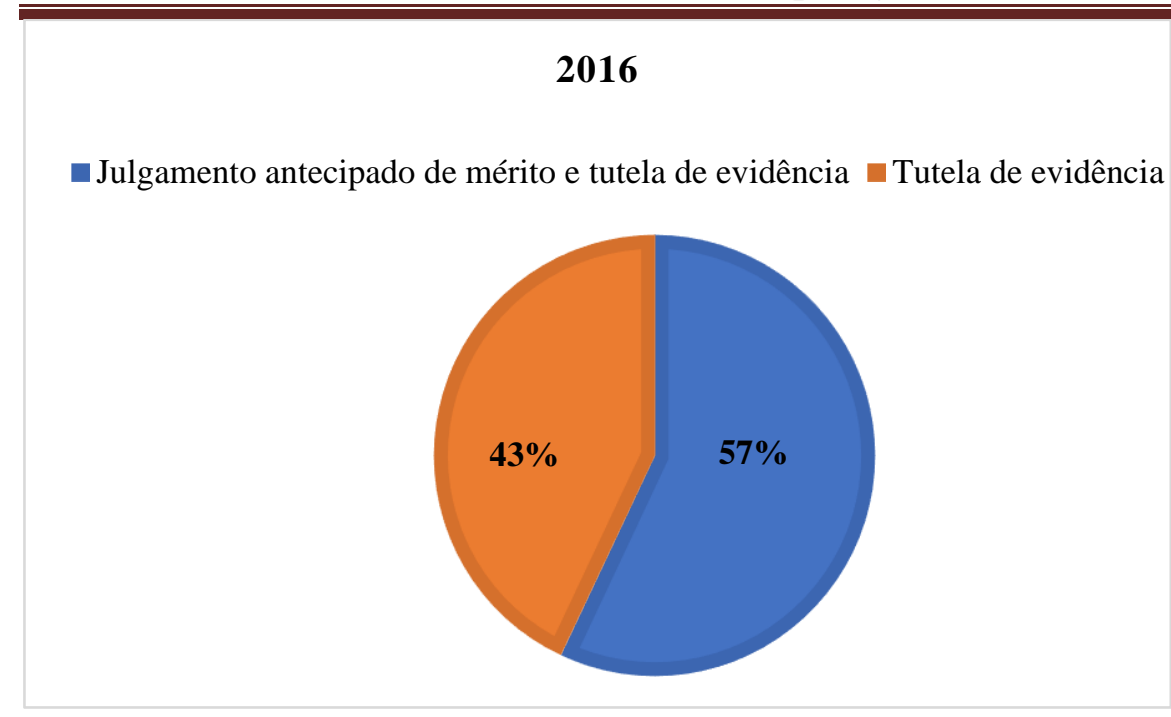

Dos 176 processos relativos ao ano de 2017, 137 tiveram o mérito antecipadamente julgado e neles foi deferida tutela de evidência; e 34 versaram apenas sobre tutela de evidência. Um dos processos teve deferida tutela de urgência e não de evidência; e um deles teve a tutela de evidência indeferida. Três dos processos apenas se referiram ao dispositivo, mas não aplicaram essa espécie de tutela provisória. Sendo assim, do total de processos que tiveram tutela de evidência deferida (171), aproximadamente $80 \%$ aplicaram a tutela de evidência no julgamento antecipado de mérito, conforme aponta o gráfico.

GRÁFICO 8 - PERCENTUAL DE DECISÕES QUE APLICAM A TUTELA DE EVIDÊNCIA CONCOMITANTEMENTE AO JULGAMENTO ANTECIPADO DE MÉRITO NO ANO DE 2017 
Revista Eletrônica de Direito Processual - REDP.

Rio de Janeiro. Ano 13. Volume 20. Número 1. Janeiro a Abril de 2019

Periódico Quadrimestral da Pós-Graduação Stricto Sensu em Direito Processual da UERJ

Patrono: José Carlos Barbosa Moreira (in mem.). ISSN 1982-7636. pp. 182-215

www.redp.uerj.br

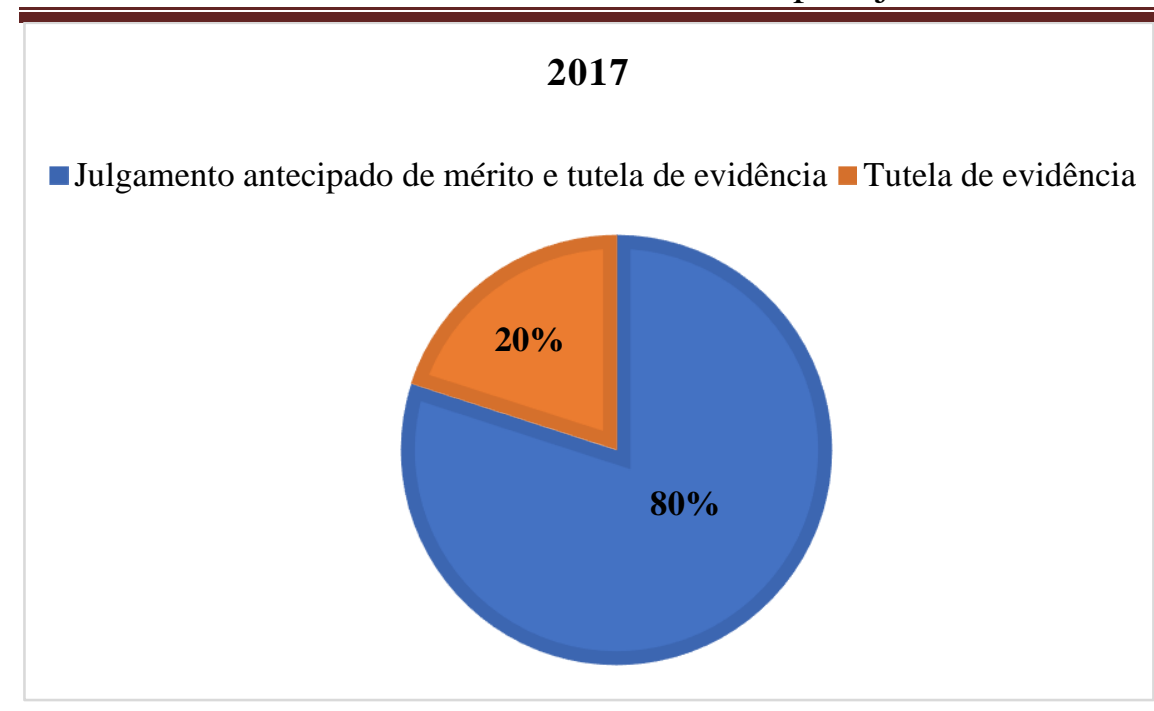

GRÁFICO 9 - APLICAÇÃO DA TUTELA DE EVIDÊNCIA EM 2016 E 2017

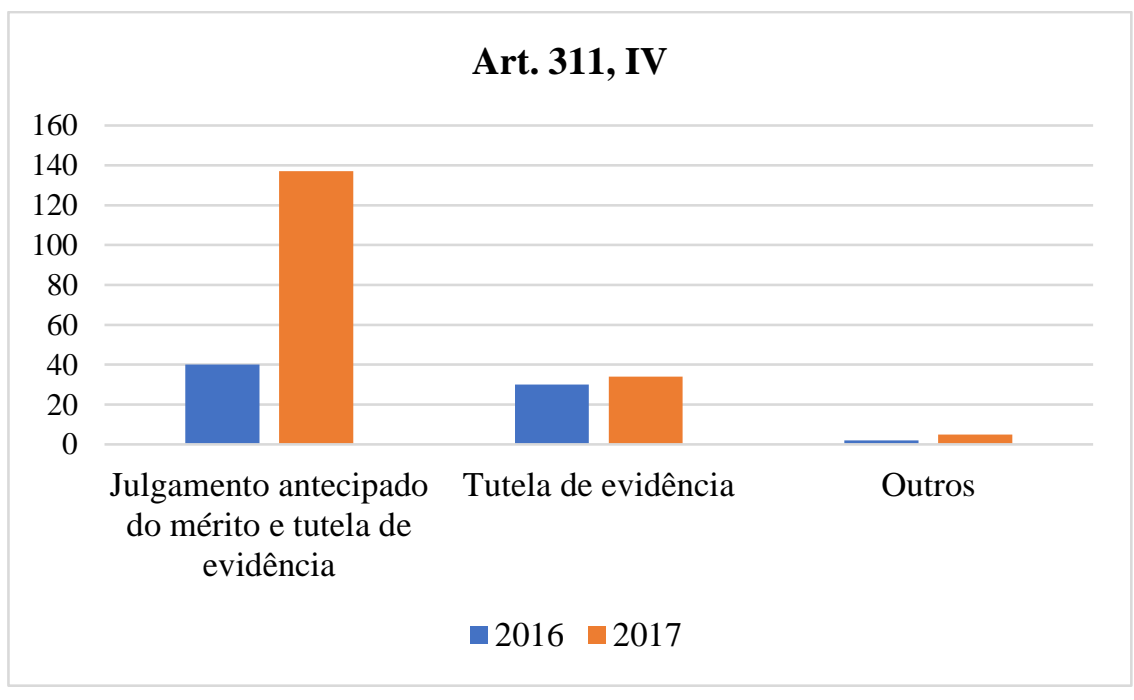

\section{CONCLUSÃO}

As verificações apontadas quanto à introdução do art. 311 do CPC reafirmam que, na busca pela duração razoável do processo, não necessariamente é a sumarização da cognição do juiz que efetivará o prazo ótimo de resolução do conflito, mas sim a eliminação de etapas de inatividade processual ${ }^{16}$, o que apenas pode ocorrer identificando-se as causas extraprocessuais da morosidade, combatendo-as pontualmente.

16 PEREIRA, Alexandre Ferrer Silva. A efetividade da Tutela Antecipada de Evidência no Estado Democrático de Direito. Rio de Janeiro: Lumen Juris, 2016. p.78-79. 
Revista Eletrônica de Direito Processual - REDP.

Rio de Janeiro. Ano 13. Volume 20. Número 1. Janeiro a Abril de 2019

Periódico Quadrimestral da Pós-Graduação Stricto Sensu em Direito Processual da UERJ

Patrono: José Carlos Barbosa Moreira (in mem.). ISSN 1982-7636. pp. 182-215

www.redp.uerj.br

Trata-se de uma constatação que já havia sido antecipada por alguns pesquisadores antes mesmo da edição do CPC/2015, no sentido de que uma nova legislação, por melhor qualidade técnica que ostentasse, não conseguiria superar os problemas atuais do Judiciário, por terem causas sociais e não processuais.

Assim, antes de qualquer reforma deveriam existir estudos multidisciplinares sobre as causas da litigiosidade ${ }^{17}$.

Cabe aqui, portanto, a crítica de que muitas das medidas introduzidas pelo legislador são aprovadas sem respaldo em dados estatísticos e em desatenção às exigências da experiência e das necessidades futuras ${ }^{18}$. Não existem, no Brasil, dados confiáveis sobre o tempo médio de duração de um processo e as causas de sua morosidade, bem como sobre o funcionamento da justiça, que permitam um diagnóstico do problema e possam nortear uma atuação mais assertiva do legislador ${ }^{19}$. Com isso, as reformas processuais atingem "superficialidades procedimentais", mas as verdadeiras causas do problema permanecem intocadas $^{20}$.

Com a positivação genérica das hipóteses de tutela de evidência do art. 311 do CPC, o legislador buscou imprimir ao texto legal a ideologia principal que norteou a reforma, que foi atribuir celeridade e eficiência ao processo, voltado a uma perspectiva gerencial do Judiciário $^{21}$.

No entanto, apesar de a exposição de motivos da nova legislação indicar que a reforma se prestaria a uma necessidade de caráter pragmático ${ }^{22}$, buscando guarnecer $\mathrm{o}$ processo civil com ferramentas que permitissem enfrentar os milhares de processos, na prática, ao menos no que toca às tutelas da evidência do art. 311 do $\mathrm{CPC}$, parecem ter um impacto pouco significativo.

Pelas análises desenvolvidas ao longo deste trabalho, o inciso IV do art. 311 é a hipótese que parece ser mais valiosa, pois foi a que conseguiu alcançar a maior quantidade de processos. Além disso, tem maior efetividade também por não ter se esgotado em outros

\footnotetext{
${ }^{17}$ PARENTONI, Leonardo Netto. A celeridade no projeto do novo CPC, Revista da Faculdade de Direito da UFMG, Belo Horizonte, n. 59, p.128, jul./dez. 2011.

${ }^{18}$ DUARTE, Ricardo Quass. O tempo inimigo no Processo Civil Brasileiro. São Paulo: LTr, 2009. p.18.

${ }^{19}$ Ibid., p.64-67.

${ }^{20}$ Ibid., p.131.

21 ALMEIDA, Matheus Guarino Sant'Anna Lima [et al]., Argumentos de justificação para as reformas processuais: uma análise semiolinguística das exposições de motivos do Código de Processo Civil de 1939 e do Anteprojeto de Reforma de 2010, Revista de Estudos Empíricos em Direito, v. 3, n. 2, p.172, jul. 2016. ${ }^{22}$ Ibid., p. 165.
} 
Revista Eletrônica de Direito Processual - REDP.

Rio de Janeiro. Ano 13. Volume 20. Número 1. Janeiro a Abril de 2019

Periódico Quadrimestral da Pós-Graduação Stricto Sensu em Direito Processual da UERJ

Patrono: José Carlos Barbosa Moreira (in mem.). ISSN 1982-7636. pp. 182-215

www.redp.uerj.br

institutos que já eram previstos no Código de Processo Civil ou ter encontrado óbices de caráter pragmático.

Portanto, a presente breve investigação empírica, baseada, exclusivamente, em dados do TJSP (que pode ser utilizado de parâmetro pelo seu gigantismo), esclarece que das quatro hipóteses inseridas pelo CPC/2015, apenas uma teve o alcance que o legislador pretendeu e comunicou na exposição de motivos do diploma.

As demais conseguem atender a casos esparsos, mas sem impactos globais no Judiciário como um todo, em especial sob a perspectiva da razoável duração do processo, que resta sem solução.

Esse esvaziamento poderia ter sido previsto pelo legislador, caso tivesse atendido às recomendações dos pesquisadores que estudam o tema e que tanto clamaram para que, antes de reformas legislativas, fossem realizados sérios estudos sobre a pertinência das reformas implementadas.

\section{REFERÊNCIAS BIBLIOGRÁFICAS:}

ALMEIDA, Matheus Guarino Sant'Anna Lima [et al]., Argumentos de justificação para as reformas processuais: uma análise semiolinguística das exposições de motivos do Código de Processo Civil de 1939 e do Anteprojeto de Reforma de 2010, Revista de Estudos Empíricos em Direito, v. 3, n. 2, p.162-182, jul. 2016.

ALVES, Vilson Rodrigues. Alienação fiduciária em Garantia: as ações de busca e depósito, a impossibilidade de prisão civil do devedor. Campinas: Millennium, 1998.

ALVIM, Arruda. Manual de Direito Processual Civil. 14. ed. São Paulo: Revista dos Tribunais, 2011.

ALVIM, José Eduardo Carreira. Ação monitória e temas polêmicos da reforma processual. 5. ed. Curitiba: Juruá, 2011.

Tutela antecipada. 5. ed. Curitiba: Juruá, 2006.

ASSIS, Araken. Processo Civil Brasileiro. v. II. t. II. São Paulo: Revista dos Tribunais, 2015.

BRASIL. Anteprojeto do Novo Código de Processo Civil. Brasília: Senado Federal, Subsecretaria de Edições Técnicas, 2010. Disponível em: 
Revista Eletrônica de Direito Processual - REDP.

Rio de Janeiro. Ano 13. Volume 20. Número 1. Janeiro a Abril de 2019

Periódico Quadrimestral da Pós-Graduação Stricto Sensu em Direito Processual da UERJ

Patrono: José Carlos Barbosa Moreira (in mem.). ISSN 1982-7636. pp. 182-215

www.redp.uerj.br

<http://www2.senado.leg.br/bdsf/bitstream/handle/id/496296/000895477.pdf?sequen ce $=1>$. Acesso em: 27 jun. 2018.

. Superior Tribunal de Justiça. Recurso Especial n. 437649. Relator: Ministro Sálvio

de Figueiredo Teixeira. Brasília. J. em 06 de fev. 2003. Disponível em: $<$ https://stj.jusbrasil.com.br/jurisprudencia/265285/recurso-especial-resp-437649-sp2002-0057540-7?ref=serp>. Acesso em: 04 jul. 2018.

BRAUN, Paola Roos. Principais tutelas sumárias à luz do Novo Código de Processo Civil: Ordinariedade versus Sumariedade. Curitiba: Juruá, 2016.

BEDAQUE, José Roberto dos Santos. Efetividade do processo e técnica processual. 3. ed. São Paulo: Malheiros, 2010.

BUENO, Cassio Scarpinella. Curso sistematizado de Direito Processual Civil: tutela antecipada, tutela cautelar, procedimentos cautelares específicos. 5. ed. v. 4. São Paulo: Saraiva, 2013.

CARVAlHO NETTO, José Rodrigues de. Da Ação Monitória: um ponto de vista sobre a Lei 9.079, de 14 de julho de 1995. São Paulo: Revista dos Tribunais, 2001.

CASTRO, Daniel Penteado. Antecipação de tutela sem o requisito da urgência: panorama geral e perspectivas no novo Código de Processo Civil. Salvador: JusPodivm, 2017.

DIAS, Jean Carlos. Tutelas Provisórias no novo CPC: tutelas de urgência e tutela de evidência. Salvador: Juspodivm, 2017.

DIDIER JUNIOR, Fredie; BRAGA, Paula Sarno; OLIVEIRA, Rafael Alexandria de. Curso de Direito Processual Civil: teoria da prova, direito probatório, ações probatórias, decisão, precedente, coisa julgada e antecipação dos efeitos da tutela. 10. ed. v. 2. Salvador: Juspodivm, 2015.

DUARTE, Ricardo Quass. O tempo inimigo no Processo Civil Brasileiro. São Paulo: LTr, 2009.

DINAMARCO, Cândido Rangel; LOPES, Bruno Vasconcelos Carrilho. Teoria Geral do Novo Processo Civil: de acordo com a Lei 13.256 de 4.2.2016. São Paulo: Malheiros, 2016.

FARIAS, Cristiano Chaves; ROSENVALD, Nelson. Curso de Direito Civil: contratos: teoria geral e contratos em espécie. 5. ed. v. 4. São Paulo: Atlas, 2015. 
Revista Eletrônica de Direito Processual - REDP.

Rio de Janeiro. Ano 13. Volume 20. Número 1. Janeiro a Abril de 2019

Periódico Quadrimestral da Pós-Graduação Stricto Sensu em Direito Processual da UERJ

Patrono: José Carlos Barbosa Moreira (in mem.). ISSN 1982-7636. pp. 182-215 www.redp.uerj.br

FGV Direito SP. Relatório ICJBrasil. São Paulo, 2017. Disponível em: <http://bibliotecadigital.fgv.br/dspace/bitstream/handle/10438/19034/Relatorio-

ICJBrasil_1_sem_2017.pdf?sequence=1\&isAllowed=y>. Acesso em: 30 jun. 2018.

FUX, Luiz. A tutela dos direitos evidentes, Jurisprudência do Superior Tribunal de

Justiça, Brasília, v. 2, n. 16, p.23-43, abr. 2000.

A tutela antecipada nos tribunais superiores, Revista da EMERJ, Brasília, v. 4, n. 13, p.65-87, 2001.

GAJARDONI, Fernando da Fonseca. Os reflexos do tempo no Direito Processual Civil,

Revista da Escola Paulista de Magistratura, São Paulo, v. 4, n. 1, p.59-79, jan./jun. 2003.

Teoria Geral do Processo: comentários ao CPC/2015. São Paulo: Método, 2017.

GOMES, Orlando. Contratos. 26. ed. Rio de Janeiro: Forense, 2007.

JOBIM, Marco Félix. Tempestividade do processo no projeto de lei do novo código de processo civil brasileiro e a comissão de juristas nomeada para sua elaboração: quem ficou de fora?, Revista Eletrônica de Direito Processual, Rio de Janeiro, v. 4, ano 4, p.116-134, jul./dez 2010.

LOPES, Bruno Vasconcelos Carrilho. Tutela Antecipada Sancionatória: art. 273, inc. II, do Código de Processo Civil. São Paulo: Malheiros, 2006.

MAIDAME, Márcio Manoel. Subsiste o efeito suspensivo na Apelação contra Sentença de Rejeição dos Embargos à Ação Monitória, no Novo CPC?, Revista da Faculdade de Direito da Universidade São Judas Tadeu, São Paulo, n. 4, p. 138-156, $2^{\circ}$ sem/2017. MARCATO, Antônio Carlos. Procedimentos especiais. 3. ed. São Paulo: Revista dos Tribunais, 1990 .

MARINONI, Luiz Guilherme; ARENHART, Sérgio Cruz; MITIDIERO, Daniel. Novo Curso de Processo Civil: tutela dos direitos mediante procedimento comum. v. 2. São Paulo: Revista dos Tribunais, 2015.

MEDINA, José Miguel Garcia. Novo Código de Processo Civil Comentado: com remissões e notas comparativas ao CPC/1973. 4. ed. São Paulo: Revista dos Tribunais, 2016.

MEDINA, José Miguel Garcia; ARAÚJO, Fábio Caldas; GAJARDONI, Fernando da Fonseca. Procedimentos Cautelares e Especiais. 4. ed. v. 4. São Paulo: Revista dos Tribunais, 2013. 
Revista Eletrônica de Direito Processual - REDP.

Rio de Janeiro. Ano 13. Volume 20. Número 1. Janeiro a Abril de 2019

Periódico Quadrimestral da Pós-Graduação Stricto Sensu em Direito Processual da UERJ

Patrono: José Carlos Barbosa Moreira (in mem.). ISSN 1982-7636. pp. 182-215

www.redp.uerj.br

MELLO, Cleyson de Moraes. Direito Civil: Contratos. 2. ed. Rio de Janeiro: Freitas Bastos, 2017.

MITIDIERO, Daniel. Antecipação da Tutela: Da tutela cautelar à técnica antecipatória. 3. ed. São Paulo: Revista dos Tribunais, 2017.

MONTENEGRO FILHO, Misael. Ações possessórias no novo CPC. 4. ed. São Paulo: Atlas, 2017.

PARENTONI, Leonardo Netto. A celeridade no projeto do novo CPC, Revista da Faculdade de Direito da UFMG, Belo Horizonte, n. 59, p.123-166, jul./dez. 2011.

PEREIRA, Alexandre Ferrer Silva. A efetividade da Tutela Antecipada de Evidência no

Estado Democrático de Direito. Rio de Janeiro: Lumen Juris, 2016.

PINHO, Humberto Dalla Bernardina de. Direito Processual Civil Contemporâneo: processo de conhecimento, cautelar, execução e procedimentos especiais. 2. ed. v. 2. São Paulo: Saraiva, 2013.

PONTES, Daniel de Oliveira. A tutela de evidência no Novo Código de Processo Civil: uma gestão mais justa do tempo na relação processual, Revista de Processo, São Paulo, v. 261, ano 41, p.341-368, nov. 2016.

PÓVOA, Liberato. Busca e Apreensão. 5. ed. Curitiba: Juruá, 2012.

RODRIGUES, Marco Antonio; RANGEL, Rafael Calmon. A tutela de evidência como técnica de atuação judicial, Revista de Processo, São Paulo, v. 271, ano 42, p.257276, set. 2017.

SCHEIDT, Emiliane. A tutela de evidência no Novo Código de Processo Civil, Revista da Escola Superior de Magistratura do Estado de Santa Catarina, Santa Catarina, v. 23, n. 29, p.183-206, 2016.

SILVA, Cassiana de Almeida e; RODRIGUES, Edwirges Elaine. Responsabilidade Civil por furto de veículos ocorrido no estacionamento de shopping center, Revista Eletrônica da Faculdade de Direito de Franca, Franca, v. 10, n. 1, p.25-66, jul. 2015. SILVA, José Gomes. Ação Monitória: primeiros comentários ao procedimento monitório no Novo Código de Processo Civil. 1. ed. Campo Grande: Contemplar, 2015.

SILVA, Ovídio A. Baptista da. Procedimentos especiais. 2. ed. Rio de Janeiro: Aide, 1993. SOUZA, Artur César de. Da tutela de evidência e da tutela satisfativa: última parte, Revista de Processo, São Paulo, v. 39, n. 235, p. 151-186, set. 2014. 
Revista Eletrônica de Direito Processual - REDP.

Rio de Janeiro. Ano 13. Volume 20. Número 1. Janeiro a Abril de 2019

Periódico Quadrimestral da Pós-Graduação Stricto Sensu em Direito Processual da UERJ

Patrono: José Carlos Barbosa Moreira (in mem.). ISSN 1982-7636. pp. 182-215 www.redp.uerj.br

THEODORO JÚNIOR, Humberto. Curso de Direito Processual Civil: processo de execução e cumprimento da sentença, processo cautelar e tutela de urgência. 48. ed. v. II. Rio de Janeiro: Forense, 2013.

TOMASEVICIUS FILHO, Eduardo. Sugestões para um futuro Código de Processo Civil, Revista da Faculdade de Direito da Universidade de São Paulo, v. 110, p.123-154, jan./dez. 2015.

TUCCI, José Rogério Cruz e. Ação Monitória: Lei 9.079, de 14.7.1995. 2. ed. São Paulo: Revista dos Tribunas, 1997.

TUCCI, Rogério Lauria. Do julgamento conforme o estado do processo: Estudo sobre uma das mais importantes inovações do Código de Processo Civil de 1973. São Paulo: José Bushatsky, 1975.

VEÇOSO, Fabia Fernandes Carvalho [et al]. A pesquisa em direito e as bases eletrônicas de julgados dos tribunais, Revista de Estudos Empíricos em Direito, v. 1, n. 1, p. 105 139, jan. 2014.

VILHENA, Luis Eduardo Freitas de. Ação de Busca e Apreensão (Decreto-lei 911/69, com as alterações da lei 10.931, de 02.08.2004). GAJARDONI, Fernando da Fonseca; SILVA, Márcio Henrique Mendes da [coords.]. Manual dos procedimentos especiais cíveis de legislação extravagante. São Paulo: Método, 2006.

WAMBIER, Luiz Rodrigues; TALAMINI, Eduardo. Curso avançado de processo civil: cognição jurisdicional, processo comum de conhecimento e tutela provisória. 16. ed. v. 2. São Paulo: Revista dos Tribunais, 2016.

WATANABE, Kazuo. Da cognição no processo civil. 3. ed. São Paulo: Bookseller, 2005.

ZAVASCKI, Teori Albino. Antecipação de Tutela. 7. ed. São Paulo: Saraiva, 2009. 